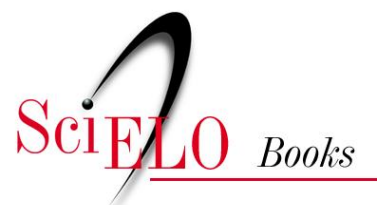

\title{
Aids na terceira década
}

\author{
Francisco Inácio Bastos
}

\section{SciELO Books / SciELO Livros / SciELO Libros}

BASTOS, FI. Aids na terceira década [online]. Rio de Janeiro: Editora FIOCRUZ, 2006. Temas em Saúde collection, 104 p. ISBN: 978-85-7541-301-2. Available from SciELO Books <http://books.scielo.org>.

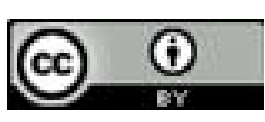

All the contents of this work, except where otherwise noted, is licensed under a Creative Commons Attribution 4.0 International license.

Todo o conteúdo deste trabalho, exceto quando houver ressalva, é publicado sob a licença Creative Commons Atribição 4.0.

Todo el contenido de esta obra, excepto donde se indique lo contrario, está bajo licencia de la licencia $\underline{\text { Creative }}$ Commons Reconocimento 4.0. 
AIDS NA TERCEIRA DÉCADA 


\title{
FUNDAÇÃO OSWALDO CRUZ
}

Presidente

Paulo Marchiori Buss

Vice-Presidente de Ensino, Informação e Comunicação

Maria do Carmo Leal

\section{EDITORA FIOCRUZ}

\section{Diretora}

\author{
Maria do Carmo Leal
}

Editor Executivo

João Carlos Canossa Mendes

Editores Científicos

Nísia Trindade Lima

Ricardo Ventura Santos

Conselho Editorial

Carlos E. A. Coimbra Jr.

Gerson Oliveira Penna

Gilberto Hochman

Ligia Vieira da Silva

Maria Cecilia de Soura Minayo

Maria Elizabeth Lopes Moreira

Pedro Lagerblad de Oliveira

Ricardo Lourenço de Oliveira

\section{Coleção Temas em Saúde}

Editores Responsáveis

Maria do Carmo Leal

Nísia Trindade Lima

Ricardo Ventura Santos 
FRANCISCO INÁCIO BASTOS

\section{AIDS NA TERCEIRA DÉCADA}

FRANCISCO INÁCIO BASTOS

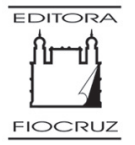


Copyright (C) 2006 do autor

Todos os direitos desta edição reservados à

FUNDAÇÃO OSWALDO CRUZ / EDITORA

ISBN: 85-7541-091-1

Capa, projeto gráfico e editoração eletrônica

Carlota Rios

Revisão

Fernando Arosa

Supervisão Editorial

M. Cecília G. B. Moreira

Catalogação-na-fonte

Centro de Informação Científica e Tecnológica

Biblioteca da Escola Nacional de Saúde Pública Sergio Arouca

B327a Bastos, Francisco Inácio

Aids na Terceira Década. Francisco Inácio

Bastos. Rio de Janeiro : Editora Fiocruz, 2006.

104 p. (Coleção Temas em Saúde)

1.Síndrome de imunodeficiência adquirida história. 2.HIV. I.Título.

CDD - 20.ed. - 614.5993

2006

EDITORA FIOCRUZ

Av. Brasil, 4036 - Térreo - sala 112 - Manguinhos

21040-361 - Rio de Janeiro - RJ

Tels: (21) 3882-9039 / 3882-9041

Telefax: (21) 3882-9006

e-mail: editora@fiocruz.br

http://www.fiocruz.br 
Para Amalia e o Povo do Livro: origem. Para Claudia e Amalia, que me convivem e continuam. 



\section{SUMÁRIO}

Apresentação

1. Máquinas Spinozianas em um Planeta Devastado: a pré-história da Aids

2. A Primeira Década:

uma série de eventos infelizes

3. A Sociedade Reage... Mas as Contradições Persistem 45

4. O Haiti Não É Aqui: viver mais e melhor 65

5. Espelho, Espelho Meu

83

Sugestões de Leituras 

Sugestões de Leituras

\section{Spinoza}

As mãos do judeu lavram transparentes

No lusco-fuso, brunindo os cristais

E medo e frio é a tarde poente (Tardes que às tardes são iguais) As mãos e o espaço de jacinto Que nas portas do Gueto empalidece Quase não há para o homem que assim tece Quieto, os sonhos de um claro labirinto. Não o turva a fama, sonhos reflexos No sonbo de outro espelho convexo Nem o amor temeroso das donzelas. Livre da metáfora e do mito Um cristal árduo lavra: É o infinito Mapa d'Ele, que é os astros e os constela.

$$
\text { Jorge Luis Borges }
$$





\section{Apresentação}

Se acaso uma cartomante me dissesse, aos 22 anos, quando decidi concluir o curso médico no internato regular, rotatório, nas especialidades clínicas, recusando o convite para ingressar num laboratório de neurofisiologia, que viria a escrever, anos depois, este pequeno livro, ponderaria eu tratar-se de rematada tolice.

Conselhos não costumam frutificar (pois, afinal, 'se valessem de algo, não seriam dados, mas sim vendidos', como se diz popularmente), mas quem sabe o meu singelo exemplo sirva aos mais jovens como confirmação de que o destino segue caminhos insondáveis, e, que por isso mesmo, cabe acreditar na intuição e não dar muitos ouvidos às pessoas de mente por demais estreita.

Revejo o rapaz de 22 anos, apaixonado por conhecimentos que, até então, julgava incompatíveis: as neurociências e a literatura. As doenças infecciosas eram, então, uma cadeira que cursei sem maior interesse, que não o de atender os pacientes de forma digna.

Em uma prateleira empoeirada, no fundo de uma livraria, descobri certo dia um velho livro do neurocientista inglês Charles Sherrington. O seu texto profundo, repleto de reflexões 
filosóficas e escrito num inglês literário da melhor estirpe, resolveu para sempre meu eterno conflito de gostos - era possível, sim, compatibilizar ciência e literatura.

Pouco tempo depois, meu apetite por livros estranhos e empoeirados (há gostos bizarros nesta vida!), me fez topar com um outro autor que viria a ser meu mestre ao longo de toda a vida, o matemático, lingüista e pensador norte-americano Norbert Wiener. Nascia, então, uma nova paixão, jamais correspondida, por uma terceira vertente do conhecimento humano as ciências ditas exatas, como a matemática, a estatística e a física.

O caminho que me conduziu desse, por si só já confuso, estado de coisas ao estudo da Aids não poderia ser mais inesperado. Inicialmente convidado a trabalhar em uma Clínica de Dor na Universidade onde estudava, constatei pela primeira vez como meus conhecimentos sobre o cérebro humano eram, não apenas insuficientes, mas, antes de tudo, incapazes de minorar o sofrimento de muitos dos meus pacientes.

Impotente diante das dores do mundo, em um sentido tanto metafórico como concreto, aceitei de bom grado o convite para trabalhar num serviço recém-inaugurado de pesquisa e assistência a usuários de drogas, onde julguei que meus conhecimentos poderiam ser, talvez, mais úteis. Nova decepção: então, com 25 anos, me deparei com as agruras da dependência química, que conhecia, até então, tão-somente pela vertente contracultural das festas e da experimentação de substâncias psicoativas diversas que caracterizaram os anos 60 e 70.

Como se não bastasse, enquanto entrevistava os pacientes e redigia minha dissertação de mestrado, comecei a ver os primeiros indivíduos acometidos por uma doença misteriosa, que, à época, diziam ser uma 'peste gay', o que não correspondia ao 
perfil dos pacientes que atendia. A perplexidade diante do que representava para mim uma terceira e definitiva derrota - a dor, a dependência e, agora, o sofrimento e a morte anunciada - me fez duvidar do acerto em escolher minha profissão, pois no meu íntimo não me sentia digno do preceito básico que havia jurado cumprir: aliviar o sofrimento humano.

Por um par de anos, praticamente me afastei da medicina, trabalhando antes como editor e tradutor de livros sobre temas os mais diversos. Decidido a voltar à medicina em tempo integral, e, agora sim, à pesquisa, resolvi enfrentar o desafio posto pela Aids munido de todos os recursos de que pudesse dispor. Passei a estudar dia e noite diversos dos seus aspectos, desde a arquitetura dos vírus aos aspectos sociais e culturais de um fenômeno que se tornara mundial. Este livro reflete algo dessa trajetória. 



\section{Máquinas Spinozianas \\ 1 I em um Planeta Conturbado: A PRÉ-HISTÓRIA DA AIDS}

$\mathbf{O}$ óptico holandês Baruch Spinoza, enquanto cortava e polia lentes, como mostra o poema em epígrafe, virou de cabeça para baixo o cânone judaico e a filosofia como um todo. Para os propósitos deste livro interessa-nos tão-somente uma das suas sentenças que, como sempre, combinam a inventividade do filósofo e a precisão do óptico (ou, antes, segundo o próprio Spinoza, a filosofia e o método de demonstração da geometria). Dizia Spinoza (em versão livre, nada geométrica) que: 'o ser almeja, antes de tudo, persistir'.

Esta sentença aparentemente singela condensa a lógica que perpassa este pequeno volume, que descreve a convivência pouco harmoniosa entre um vírus (o HIV, vírus da imunodeficiência humana) e os seres humanos.

O primeiro dos termos dessa relação, o HIV, é uma 'máquina spinoziana', no sentido mais preciso da expressão, ou seja, um ser que não é movido por outro propósito que não seja o de persistir. E o faz da forma mais eficiente, plástica e econômica que se conhece na natureza. Eficiente, pois é capaz de escapar aos mais devastadores ataques que lhes movem os organismos que parasita, e adaptar-se às mais variadas circunstâncias. Plástica, não no sentido da beleza (embora deva haver os que os julgam belos), mas de 'plasticidade', capacidade de ser flexível, o que no seu caso extrapola a 'adaptabilidade' antes mencionada, mas inclui algo que nós, seres humanos, não somos capazes de 
fazer (a não ser em um sentido metafórico): reconstruir-se. Finalmente, econômica, pois o vírus praticamente nada gasta de si mesmo para se perpetuar; tudo que usa, toma emprestado do organismo que parasita. Econômica também no sentido da 'parcimônia' (conceito que provém de um outro filósofo, o frade inglês William de Ockam; mas esta já é uma outra história), ou seja, a propriedade de que, entre todos os caminhos possíveis para obter seus propósitos, utilize-se, invariavelmente, o caminho mais curto, direto e conciso.

Plástica, não no sentido da beleza (embora deva haver os que os julgam belos), mas de plasticidade, capacidade de ser flexível, o que no seu caso extrapola a adaptabilidade antes mencionada, mas inclui algo que nós, seres humanos, não somos capazes de fazer (a não ser em um sentido metafórico).

Como diz outro holandês, o virologista Jaap Goudsmit, importante cientista de nosso tempo, os vírus nos precedem no planeta Terra, permeiam nossas vidas e, muito provavelmente, se viermos a desaparecer enquanto espécie, nos sobreviverão, vindo a parasitar outros seres, menos complicados e destrutivos do que os seres humanos.

O outro termo da relação somos nós, seres humanos, que almejamos persistir, não apenas enquanto espécie, mas antes e acima de tudo, enquanto indivíduos. O fato de sermos antes de tudo indivíduos e termos aguda consciência disto nos faz, simultaneamente, sublimes e cruéis, capazes de dar origem a um Spinoza, mas também a um Hitler, de agir com "engenho e arte" (como escreveu Camões), mas também de destruir nossos próximos e o meio-ambiente com requinte, sistematicidade e indiferença. Os destinos do planeta Terra estão hoje, para o mal e para o bem, nas mãos desta complicada e contra- 
ditória variedade de símios, nós, os homens ditos sapiens, ou seja, aqueles que sabem.

A crônica da Aids é a crônica dessas duas populações em conflito, vírus e humanos, cada uma delas almejando perpetuar-se às expensas da outra. Trata-se de uma crônica do que há de pior e melhor na alma humana, já que as ameaças prementes à nossa integridade sempre fizeram e fazem aflorar o que há de pior e melhor de nós. A crônica das antigas epidemias, como, por exemplo, o Diário do Ano da Peste, do escritor inglês Daniel Defoe, permite compreender a profunda dimensão da resposta humana às epidemias.

Como veremos ao longo deste livro, a história da Aids compreende, infelizmente, relatos degradantes de estigmatização e marginalização de pessoas percebidas (o mais das vezes, de forma completamente equivocada e preconceituosa) como sob risco de contrair e/ou transmitir a infecção, e, especialmente, de pessoas vivendo com a infecção (pelo HIV) e/ ou com a síndrome clínica (Aids). Felizmente, compreende também histórias de solidariedade e altruísmo, mobilização social e os avanços de uma ciência praticada com ética e qualidade. Mas voltemos às nossas máquinas spinozianas, plásticas e parcimoniosas, os vírus.

A versão mais aceita hoje entre os biólogos com relação ao início da vida na Terra, combina: 1) compostos inorgânicos que serviriam de molde/suporte a interações que poderíamos já denominar 'orgânicas' ou 'vivas'; 2) os constituintes básicos dos organismos vivos, como as proteínas (entre outros); e 3) sistemas de guarda e transmissão de informação.

Estas questões são bastante complexas, e só é possível explicálas aqui de uma forma extremamente resumida e simplificada, 
que talvez enfureça os biólogos. Mas, enfim, correndo o risco de uma recriminação justificada, é possível exemplificar o meio onde teriam ocorrido as interações primitivas das primeiras formas que poderíamos denominar 'vivas', através da água dos oceanos primitivos (condição de solubilidade das partículas) e/ ou da argila, enquanto possível molde; exatamente, como hoje precisamos da água para viver e utilizamos jarros de cerâmica para contê-la e transportá-la (obviamente, há alternativas tecnológicas mais eficientes para conter e transportar líquidos, como os encanamentos, mas estamos falando aqui de um mundo préhumano e, portanto, pré-tecnológico).

O segundo elemento são as proteínas, e aí já estamos na interface entre não-vida e vida, questão que é familiar ao leigo que lê nos jornais sobre o 'mal da vaca louca', que é causado por uma proteína que os especialistas hesitam em definir como um agente infeccioso (um parasita) propriamente dito: o príon.

Antes de tudo, a vida persiste, como disse Spinoza, e para isso tem de se reproduzir a partir de uma estrutura definida, estrutura esta que exige, para sua definição e conformação, informação.

Recapitulando: a vida precisa inicialmente de um suporte/ meio de interação, de materiais com que construir estruturas a serem reproduzidas (as proteínas, entre outros compostos), além de energia e de informação que oriente a construção da estrutura. Ainda está complicado? Pense então em um canteiro de obras (o molde ou palco das interações). São necessários tijolos, telhas, cimento (materiais); mão-de-obra e máquinas (elementos de transformação e aporte de energia); mas também um mestrede-obras e uma planta, elementos que sistematizam e veiculam a informação. 
E o que isso tem que ver com a Aids? Tudo!

$\mathrm{O}$ vírus da Aids, o HIV, é uma máquina composta por um punhado de proteínas (como dissemos, apenas as essenciais, pois ele rouba de nós tudo mais de que necessita); uma unidade de informação, denominada RNA viral (voltaremos a este ponto), que necessita de recipientes e/ou líquidos que o suportem e transportem, que são nossas células e os líquidos que trocamos quando interagimos com outros seres humanos: no caso específico do HIV \% sangue, líquido seminal e vaginal.

O HIV é um retrovírus, ou seja, um vírus que trafega ao contrário (de frente para trás - "retro"). A natureza opera, habitualmente, segundo planos lógicos de estrutura/construção não propositais ou finalísticos (normalmente designados pelo termo alemão Bauplan; mas isso nos levaria muito longe), mas não conta exatamente com sinais de trânsito, como nossos automóveis. Portanto, a idéia de um vírus que trafega na contra-mão só pode ser compreendida se entendermos antes o que em biologia se concebe como a 'mão' do tráfego de informações. Esta mão foi estabelecida no âmbito de algo que seus formuladores $\%$ o biólogo Watson e o físico Crick, quando trabalhavam na Inglaterra, nas décadas de 1950 e 1960 - denominaram "dogma central da biologia". Resumidamente, acreditavam eles que a informação em biologia fluiria sempre numa única direção: a partir de moléculas capazes de guardar e transmitir informação (os ácidos desoxiribonucleicos, ou, simplesmente, DNA, na sua sigla inglesa), daí para moléculas que combinam a guarda e transmissão de informação com algumas características mais operacionais (os ácidos ribonucléicos, ou RNA), e daí para as proteínas. Ou seja, mantida a metáfora da construção civil: os arquitetos/ engenheiros (DNA) transmitiriam as informações para os 
mestres-de-obra (RNA), e estes às proteínas (a um só tempo, operários e tijolos. O leitor há de convir que se trata de uma metáfora abusiva, mesmo para o velho Karl Marx, que falava na coisificação e vilificação da mão-de-obra).

Habitualmente, dogmas costumam encontrar pela frente 'espíritos-de-porco', que os contestam com argumentos, ou neste caso, exemplos. E não é que a natureza deixou de ler esta parte dos artigos de Watson e Crick! E quem aparece em cena são exatamente os retrovírus, capazes de trafegar a via da informação na contramão, ou seja, transmitir informação ao contrário, do RNA para o DNA.

Isso os torna ainda mais plásticos, econômicos e adaptáveis, formidáveis adversários para nós, humanos, que pretendemos combatê-los e, se possível, eliminá-los! Retomando a surrada metáfora da construção civil, pela última vez (promessa!), teríamos aqui mestres-de-obra que prescindem de arquitetos/engenheiros, ou antes, os constroem, segundo seus desígnios. Com isso, constroem de forma ágil, mas - louvados sejam os arquitetos e engenheiros! - , estão mais sujeitos a erros, pois a operação de formar arquitetos e engenheiros a partir da habilidade exclusiva dos mestres-de-obras é uma operação arriscada. É exatamente isto o que faz o HIV, que, a partir do seu saber de mestrede-obra (RNA), forma engenheiros/arquitetos (DNA), como uma faculdade de 'fundo-de-quintal'. A operação (que, academicamente, seria ilícita) é feita com a ajuda de uma enzima (uma espécie de faz-tudo da biologia, sempre disposto a auxiliar e apressar o serviço alheio) denominada transcriptase reversa. A designação desta enzima não poderia ser mais precisa, pois o que ela faz é exatamente traduzir um código em outro código (transcriptar) no sentido inverso ao habitual (reverso, pois, não 
resta dúvida de que, no seu conjunto, a natureza aprecia os artigos de Watson e Crick!).

A propensão ao erro em uma obra, freqüentemente, resulta em desastre, com desabamentos e vítimas, e é isso o que ocorre, no mais das vezes, nos seres complexos como nós, humanos, mas não nos econômicos, parasitários e plásticos vírus. Para nós, humanos e outros animais complexos, a maioria das 'mutações' (este o termo biológico para o erro da reprodução estrutural frente à estrutura original) é deletéria e está associada a malformações e doenças. Mas este não é o caso dos vírus, máquinas que não operam segundo a lógica humana, de indivíduos, mas sim, segundo a lógica implacável da sobrevivência da espécie. Que um ou mesmo dezenas de soldados pereçam pelo caminho em função de mutações desastradas que os tornam inoperantes, pouco importa para este exército sem general ou propósito, que não seja o de reproduzir e, se possível, ampliar (e, ao ampliar, garantir, em tese, sua preservação no tempo e espaço) sua própria força bélica.

Não que a mudança de estrutura dos vírus não traga ônus para suas operações, como um soldado que tivesse de utilizar pesadas roupas térmicas para suportar um frio intenso. Com certeza, traz, e este preço é denominado em biologia evolutiva 'custo'. Sem dúvida, os soldados que combatem sob condições climáticas mais propícias se movem de forma mais ágil, mas entre pagar um preço (e aumentar o 'custo' de sobreviver) e não mais persistir, nossas máquinas spinozianas seguem em frente, menos ágeis, mas vivas!

A lógica do tratamento anti-retroviral (ou seja, de combate aos retrovírus), tema que retomaremos mais à frente, é exatamente esta: encurralar este formidável exército de milhões de 
seres que copiam a si mesmos sem cessar (daí o termo biológico "cópias virais"), impondo-lhe custos crescentes à sua expansão, até então, irrefreável, colocando em seu caminho uma série de obstáculos - de instalação súbita, precoce e coordenada. Não é outro o sentido da frase do criador da terapia combinada antiAids (conhecida popularmente como 'coquetel'), David Ho, de bater 'precocemente, e de forma dura' nos vírus.

Sabe-se hoje que o HIV circula, no mínimo, há décadas. Alguns dos seus primos (outros retrovírus) são infinitamente mais antigos, e circulam há dezenas ou mesmo centenas de milhares de anos nos seus diferentes hospedeiros, o que inclui felinos (como os nossos gatos domésticos, que padecem da leucemia felina, causada por um retrovírus) e diversas espécies de macacos. Existe mesmo uma forte evidência de que a placenta, que caracteriza o amplo conjunto de mamíferos placentários (ou seja, quase todos os mamíferos hoje existentes, com exceção dos cangurus e de outros mamíferos não-placentários australianos), seja proveniente da interação entre o nosso (mamíferos) genoma e parte do genoma de um retrovírus (e sua respectiva capacidade de síntese estrutural). Portanto, se não fosse por uma espécie de acordo diplomático entre as progenitoras de nossas mães e um retrovírus que decidiu parasitá-las, teríamos todos passado parte das nossas vidas em bolsas, como os cangurus. Não resta dúvida de que os retrovírus nos pouparam dos eventuais constrangimentos de viver dentro de bolsas.

Esta última sentença talvez faça com que o leitor tenha vontade de fechar este livro, face ao descrédito provocado pela capitulação pacata de um exército aguerrido frente ao seu inimigo. Mas, tenhamos calma, reside aí a plasticidade maior dessas formidáveis máquinas de combate, que também conhecem as be- 
nesses da paz. Diante de um inimigo incômodo ou por demais poderoso, por que não propor um armistício e conviver de forma pacata? Esta é uma alternativa sempre em aberto para retrovírus e demais parasitas (a ponto de, equivocadamente, diversos biólogos terem suposto, que a longo prazo, todo conflito terminaria em armistício entre facções de parasitas e hospedeiros).

A paz entre retrovírus (e vírus em geral) e seus hospedeiros tem características especiais, dado que não se trata de uma simples trégua, mas sim de uma situação em que o antigo inimigo se incorpora (funde) àquilo que combatia até então. Incorporações similares a esta (num sentido metafórico, e não biológico) foram diversas vezes tentadas na história humana, mediante a utilização da força ou da persuasão e fusão cultural, quase sempre sem sucesso (a resistência dos gauleses a se fazerem romanos inspirou diversas obras, desde o livro clássico de César sobre a guerra da Gália até os quadrinhos de Asterix). Neste sentido, os vírus se parecem com gauleses que se tornaram mais romanos que os romanos, conservando-se, no entanto, simultaneamente, gauleses (algo inimaginável em termos humanos). Persistirão daí em diante como parte dos seus hospedeiros e viverão enquanto estes viverem. Mas nem sempre a trégua é eterna, e, sob condições adversas, os antigos guerreiros podem retomar sua vida de batalhas, freqüentemente, de forma desastrosa, por exemplo, induzindo o crescimento desordenado das células do hospedeiro e causando o câncer.

Muita tinta (e tonner) foi gasta com detalhes bizarros acerca da 'passagem' dos retrovírus dos macacos para os humanos, questão que permanece em aberto, a despeito de publicações de natureza voyeurística, quando não racista, que descrevem em 
supostos detalhes as relações sexuais entre macacos diversos e tribos africanas. Em palestras e debates de que participei à época, fui inquirido acerca das supostas relações afetivo-sexuais entre macacos e humanos, que uns julgavam consensuais e outros conflituosas. Numa vertente claramente preconceituosa, procurou-se aproximar os macacos a uma suposta 'natureza primitiva' de determinadas tribos, como se não fôssemos, todos, primos dos chimpanzés, sob as bênçãos do Dr. Darwin, e precisássemos recorrer a uma suposta animalidade e primitividade de 'alguns' homens para imaginarmos o fluxo viral entre antropóides não humanos e nós, antropóides demasiado humanos.

Não resta dúvida, hoje, de que a Aids provém do continente africano, o que não constitui, entretanto, novidade alguma, pois nós, humanos, também somos de lá provenientes. Portanto, nós, boa parte dos símios (e diversos outros animais) e dos retrovírus (e demais vírus) nos originamos, todos, deste que é o berço principal da biodiversidade e da civilização humana (esta última, basicamente na região acima do Sahara, mais propícia à agricultura em larga escala, em conexão com parte do Oriente Médio). Vírus são máquinas spinozianas, mas de forma alguma racistas ou chauvinistas, e persistem onde mais lhes convêm, sem preferência de raça, cor, opção sexual ou credo, como rezam as legislações de todas as sociedades e culturas. Ao que parece, apenas os vírus cumprem à letra as legislações antidiscriminação, já que nós, humanos, não nos cansamos de discriminar e estigmatizar uns aos outros.

A questão central não é saber se, eventualmente, alguém manteve uma relação sexual com um símio, da mesma forma que a atual disseminação da gripe das aves não nos permite precisar a importância relativa da ingestão de carnes de aves mal cozidas, 
da manipulação das aves em granjas, do contato fortuito com aves migratórias etc., mas sim de identificar um conjunto de meios/vias de 'tráfego viral' (a expressão é de Morse, virologista norte-americano, e não do homônimo, inventor do código telegráfico) de um possível ancestral comum dos vírus das imunodeficiências símia (SIV) e humana (HIV), compreendendo diversas formas de contato sangüíneo (por exemplo, arranhaduras e/ou mordidas) ou a ingestão de carne mal-cozida de macacos por parte de membros das tribos africanas, o que em tudo se assemelha ao que é comumente observado entre os indígenas brasileiros, que domesticam animais silvestres, inclusive macacos. A par dos macacos que são tratados como animais de estimação, as diferentes tribos indígenas consideram diversas variedades de macacos finas iguarias e, neste caso, deles se alimentam.

Retomando o fio de raciocínio dos sábios holandeses, recorro ainda uma vez a Goudsmit que, numa homenagem não explícita (que me lembre) ao seu ilustre compatriota Spinoza, enxerga a questão no contexto mais abrangente da persistência, a qualquer preço, dos vírus. Em síntese, argumenta o virologista, em um mundo em que os antropóides (como gorilas, chimpanzés e orangotangos) são hoje, infelizmente, raros remanescentes de uma vasta população nativa, e estão quase inteiramente limitados a zoológicos e a algumas poucas reservas, talvez a caminho da extinção, o que resta aos guerreiros spinozianos se não ceder para conquistar. Por que não abandonar seus já habituais hospedeiros, a quem já não incomodam tanto (e vice-versa), a caminho de "mares nunca dantes navegados", como disse Camões, ou seja, rumo a estes outros símios, que andam eretos, tem menos pêlos e se reproduzem de modo formidável, pressionando 
os recursos do planeta inteiro com um contingente populacional que totaliza bilhões.

Obviamente, não é o caso de imaginar vírus maldosos, esfregando as mãos e lambendo beiços virtuais, diante do hipotético repasto oferecido por, por exemplo, um bilhão e 300 milhões de chineses. Trata-se, de fato, de um salto casual, no escuro das cadeias de transmissão de diversos agentes infecciosos, na direção dos únicos seres que, por existirem em imenso número, constituem hospedeiros viáveis e veículos para a sua persistência.

Epidemias exigem sempre uma densidade mínima de potenciais hospedeiros (ditos 'suscetíveis', na linguagem da modelagem matemática das doenças infecciosas). Não por coincidência, como explicam o inglês Anderson e o anglo-australiano May, grandes felinos de hábitos solitários, como as onças e os tigres, estão praticamente a salvo de epidemias nos moldes da Aids, embora sejam bastante parasitados pelos assim denominados 'macroparasitas', como os vermes, que persistem em hospedeiros intermediários e no meio-ambiente.

A despeito de todos os nossos esforços, mas, antes de tudo, graças à nossa inação, complacência, hipocrisia e falta de solidariedade para com o próximo, o que era uma infecção restrita a uns poucos antropóides não humanos, que vinham resistindo bravamente a seus primos, antropóides humanos, e a umas poucas tribos africanas, que vinham igualmente resistindo às guerras civis, fome, racismo e exploração econômica, se transformou em uma pandemia. Hoje, em todos os continentes e recantos deste mundo, é possível constatar o triunfo das máquinas spinozianas sobre nós. São mais de 30 milhões de pessoas vivendo com o HIV e a Aids, em todo o mundo, em uma das maiores pandemias da história. Mas isto ultrapassa a pré-história da Aids, pois é já história, e este é o tema do nosso segundo capítulo. 


\section{A Primeira década: \\ 2 I UMA SÉRIE DE COINCIDÊNCIAS INFELIZES}

Inicio este capítulo de forma similar ao anterior, recorrendo uma vez mais a um pensador judeu heterodoxo, desta feita alemão, Walter Benjamin, cuja obra não guarda qualquer relação direta com a temática da Aids, até mesmo porque Benjamin se suicidou no contexto da perseguição nazista durante a Segunda Guerra Mundial, ou seja, décadas antes do advento da epidemia.

Novamente, não vou me ater à letra do texto benjaminiano, mas sim à idéia mais geral que um dos seus textos veicula. Neste texto, Benjamin analisa um quadro do pintor Paul Klee (1879-1940) e afirma, entre outras coisas, que a história dos vencidos está por ser escrita, pois é ela apenas um resíduo da história, arrogante, dos vencedores (o leitor interessado deverá recorrer aos originais plástico-poéticos da dupla Klee-Benjamin para uma apreciação da complexidade da obra de ambos).

Pois é exatamente isso o que aconteceu à história da Aids na África subsahariana. Nos primeiros anos da década de 1980, ela simplesmente inexiste! O que todos sabem é que a partir de casos de pneumonia atípica e de um câncer raro (Sarcoma de Kaposi) em homens jovens, previamente saudáveis, em sua maioria homossexuais masculinos, nas cidades de Los Angeles, São Francisco e Nova York, os Centers for Diseases Control and Prevention - CDC (Centros para a Prevenção e Controle das Doenças), dos EUA, identificaram uma nova e misteriosa 
síndrome. Após inúmeras marchas e contramarchas, erros e acertos por parte de diversos epidemiologistas e infectologistas, chegou-se à definição e caracterização de uma nova síndrome, a Síndrome da Imunodeficiência Adquirida (cuja sigla é Sida ou Aids, esta última em língua inglesa, que nós, brasileiros anglófonos, adotamos).

A outra e principal epidemia, a que vinha afetando a população dos países africanos ao sul do deserto do Sahara, havia passado até então despercebida aos olhos da mídia e da ciência ocidental e, portanto, existia de fato, sem que 'existisse' para a ciência ocidental e a opinião pública. Não resta hoje qualquer dúvida de que o agente causador da epidemia, o HIV, teve sua origem na África, havendo mesmo um tipo de HIV, o HIV-2, que jamais abandonou suas raízes africanas e que 'não' está associado à pandemia (causada por seu primo-irmão, o HIV-1). Muito provavelmente, na ausência de um sistema de vigilância eficiente, diversos casos da nova síndrome emergiram na África ao longo da década de 1970 e início da década seguinte sem que fossem identificados enquanto tais, mas sim, enquanto algo que afetava um contingente adicional de pessoas que faleciam em virtude de infecções graves (já que o Sarcoma de Kaposi, que é um câncer causado por um vírus, jamais foi tão prevalente entre os africanos como entre norte-americanos e europeus vivendo com HIV/ Aids). Em um contexto de um sem-número de infecções, desnutrição, guerras civis e miséria, não foi possível compreender que uma nova ameaça à humanidade estava a caminho. Aliás, um exemplo dessa situação em que diversos males se superpõem (o que o antropólogo norte-americano Merril Singer denominou 'sindemia' ou 'sinergia de pragas') emergiu nos estudos referentes a surtos do vírus Ebola, que tiveram lugar em torno 
do rio homônimo (localizado na República Democrática do Congo, antigo Zaire) e regiões próximas. As análises referentes a amostras de sangue de pacientes que faleceram em virtude da infecção pelo Ebola evidenciaram que diversos pacientes estavam também infectados pelo HIV, sem que isso tivesse sido sequer notado.

A epidemia haitiana, que analiso brevemente a seguir, e que se assemelha àquela que teve e tem lugar na África subsahariana, encontrou no médico e antropólogo Paul Farmer um historiador em quem a paixão pela vida humana não embaçou a mirada crítica. A epidemia africana também tem sido objeto de inúmeras análises, algumas delas de cunho histórico e antropológico. Provavelmente por se tratar da crônica de um vasto conjunto de sociedades e culturas (que se expressam em diversas línguas locais) ainda não dispomos (que eu saiba) de uma história que articule de forma integrada suas múltiplas facetas, nos moldes da breve história que contarei a seguir: A Fábula dos $4 \mathrm{H}$.

\section{OS 4 HS: UMA FÁBULA MODERNA}

A fábula dos $4 \mathrm{Hs}$ foi tecida por epidemiologistas equivocados (e digo isso com tranqüilidade, pois esta é a profissão que abracei, cometendo também inúmeros equívocos, talvez não tão preconceituosos, espero!) e não pela sabedoria popular. Em se tratando de uma fábula científica e moderna (ou pós-moderna) não conta ela com príncipes, princesas ou fadas, embora conte com um excesso de bruxas...

As raízes dessa fábula contemporânea remetem ao clima de caça às bruxas, bruxas essas plasmadas pelos próprios fabuladores, talvez em busca de apoio a uma visão maniqueísta do 
mundo: de um lado, os saudáveis, do outro, os doentes, estes últimos, por seu turno, subdivididos em: 'vítimas inocentes' e (supostos) 'culpados'. Categorias estranhas que um hipotético HIV dotado de consciência crítica classificaria como mais uma bizarrice desses estranhos seres humanos, prova definitiva dos seus desvarios.

Enquanto os homens construíam suas falsas categorias classificatórias, não custa imaginar um vírus com um sorriso mordaz no canto da boca (nos moldes dos pequenos demônios que povoam a ficção do genial Isaac Bashevis Singer, prêmio Nobel de literatura), dizendo para si mesmo: "e eu que só almejava persistir, e procurei os caminhos que me pareceram mais fáceis de trilhar, enquanto os homens atribuíam a mim ocultas preferências por homossexuais masculinos (H1), haitianos (H2), hemofílicos (H3) e heroinômanos (H4)". Acompanhando o sábio e mordaz HIV pensante, vamos explicar a seguir como a má ciência construiu as fábulas que o pensamento crítico (científico ou não) levou anos para desconstruir.

Talvez ocorra ao leitor a idéia de que é fácil evidenciar erros a posteriori, a partir de uma confortável visada retrospectiva. Mas, ainda que não reste dúvida de que momentos de crise e dúvida nos colocam em dilemas que, no calor da ocasião, não é possível compreender e enfrentar, cabe assinalar que as ferramentas conceituais e metodológicas necessárias à correta análise da dinâmica da epidemia que então emergia já existiam e foram empregadas de forma apropriada por um pequeno grupo de pesquisadores. Retomarei este ponto mais adiante, com exemplos concretos da pesquisa inovadora desenvolvida no início dos anos 80. O fato de que ela fosse então minoritária não quer dizer, de forma alguma, que ela não existisse. 
0 primeiro $\mathrm{H}$ : os homossexuais masculinos ou 'a cena gay ocidental'

Os anos 1960 foram, nos EUA e demais países ditos 'ocidentais' (o foram também nas várias 'periferias do mundo', de forma algo distinta, o que não será abordado aqui), um momento de transformação social e protesto, com a emergência de movimentos sociais de grande envergadura, como o movimento contra a guerra do Vietnã (ou pacifista, em um sentido mais amplo), de afirmação étnica/anti-racista, feminista e de diferentes minorias, como as minorias sexuais.

A crônica desses movimentos ultrapassa, em muito, os modestos propósitos deste livro. Limito-me a descrever brevemente a dinâmica da cena gay contemporânea, duramente afetada pela eclosão da Aids.

A história é composta de fluxos contínuos (ou 'fortes ventos', segundo a dupla Klee-Benjamin), mas para contá-la é necessário estabelecer marcos. Tome-se, então, como marco inaugural da luta pelos direitos civis dos homossexuais norte-americanos a Revolta de Stonewall. A Revolta de Stonewall já foi cantada em prosa e verso (e no CD The Stonewall Celebration, EMI, de 1997, do compositor e cantor brasileiro Renato Russo). Basicamente, é possível descrevê-la como uma série de querelas entre a nascente militância gay e as forças policiais de Nova York, a partir de uma incursão policial nas adjacências do bar Stonewall Inn, localizado no Village, culminando em um conflito aberto e uma mobilização sem precedentes da comunidade gay nova-iorquina.

Emergindo de um contexto de repressão e ilegalidade (ilegalidade esta que persiste em diversos estados norte-americanos até hoje, nas assim denominadas 'leis anti-sodomia'), a cena 
gay se moveu no sentido exatamente oposto: de exaltação da liberdade sexual, orgulho pela condição homossexual (gay pride) e engajamento político, através, principalmente, de movimentos sociais de base comunitária. Foi exatamente esta cena movimentada, dinâmica e que tinha a sexualidade como elemento essencial e definidor das identidades pessoais, que foi marcadamente atingida pela disseminação do HIV, provavelmente ao final da década de 1970 (com reflexos evidentes na década subseqüente).

A partir da inegável disseminação do HIV na cena gay, uma mistura de má ciência e preconceito forjou a fábula do primeiro H. Uma primeira vertente (que, por incrível que pareça, ainda tem seus defensores até hoje, transcorridas três décadas de pesquisas!) propôs que a nascente síndrome não seria decorrente de uma patologia infecciosa, mas sim de um problema secundário ao uso de substâncias muito freqüentemente consumidas na cena gay daqueles dias: o nitrito de amila, popularmente conhecido como popper. O isolamento do vírus posteriormente denominado HIV, em 1983, por uma equipe de pesquisa francesa (cuja prioridade foi posteriormente contestada por uma equipe rival, norte-americana) tornou esta hipótese do caráter não infeccioso da Aids indefensável entre os pesquisadores responsáveis e, posteriormente, insustentável aos olhos da opinião pública.

Quase simultaneamente foi gestado o segundo desdobramento da fábula $\mathrm{H} 1$, que afirmava que a síndrome seria uma afecção exclusiva de homens gays, no que viria a ser popularmente conhecido como 'câncer gay' ou, ainda, numa vertente aparentemente mais sofisticada, a então denominada GRID (gay-related immunodeficiency ou 'imunodeficiência relacionada aos gays', ou ainda, numa tradução ao pé-da-letra, ([relacionada a] 
'ser gay'). Ou seja, a humanidade se subdividiria daí em diante em duas supostas metades: gays, sob risco absoluto de contrair o HIV/Aids, e não-gays, a salvo do misterioso mal. Enquanto isso, a epidemia avançava velozmente na África subsahariana na ausência de qualquer cena gay (obviamente, isso não quer dizer que não existam homossexuais masculinos na África, mas certamente não uma cena gay nos moldes ocidentais, exceção, à época, das metrópoles sul-africanas), basicamente através de relações heterossexuais sem o uso de preservativos (que eram, então, pouco utilizados, e com finalidade basicamente anticoncepcional).

Mas a suposta essencialidade do câncer gay foi desmontada aos olhos dos formadores de opinião pública dos países desenvolvidos, com o aparecimento de casos de Aids entre os demais $\mathrm{H}$, o que veremos mais adiante. No entanto, nos moldes das bonecas russas de madeira, que vão 'gerando', sucessivamente, bonequinhas cada vez menores, nasce um terceiro desdobramento dos equívocos anteriores, extremamente danoso para as ações preventivas, persistindo ao longo de décadas - a suposta exclusividade da relação anal como modo de transmissão do HIV e a suposta invulnerabilidade dos homens heterossexuais ao HIV transmitido a partir de mulheres infectadas.

Não resta dúvida, hoje, de que a transmissão a partir do sexo anal (desde que não sejam utilizados preservativos, ou, no jargão epidemiológico, desde que se pratique o sexo 'desprotegido') é bastante mais 'eficiente' (do ponto de vista da transmissão ou do nosso interlocutor hipotético, o vírus autoconsciente) do que a transmissão vaginal, ainda que, no âmbito de uma parceria heterossexual em que existam ambas as práticas - vaginal e anal - a transmissão vaginal do HIV seja muito mais relevante, simplesmente, por ser mais freqüente, e, com isso, fazer com 
que o parceiro eventualmente não infectado esteja sujeito a uma exposição repetida ao HIV a partir da relação sexual desprotegida com o parceiro infectado.

Ou seja, não resta dúvida de que a cena gay foi e (em diversos contextos) continua sendo bastante afetada pela disseminação do HIV. Não resta dúvida também de que a prática do sexo anal desprotegido está fortemente associado à transmissão do HIV. O problema é que isso se fez às custas da negligência com relação à prevenção da transmissão do HIV entre homens que 'não' fazem sexo com outros homens e das mulheres de um modo geral, um equívoco grave, que custou inúmeras vidas. A outra face perversa dos equívocos cometidos foi a estigmatização de todo um conjunto de pessoas a partir de suas práticas sexuais, comportamentos e atitudes, o que se revestiu de conotações moralistas e religiosas (na minha opinião, a partir de uma leitura preconceituosa dos textos fundamentais das diferentes religiões, mas, enfim, este é apenas um ponto de vista pessoal em um campo atravessado por polêmicas atrozes).

Ou seja, trata-se de uma história mal-contada, que incorre num essencialismo de todo estranho à biologia, pois, repito, o vírus almeja (de forma não proposital, é óbvio) tão-somente persistir, e encontrou nesta cena fortemente interativa, interconectada, onde as relações sexuais (à época, quase sempre desprotegidas) contribuíam fortemente para estabelecer vínculos afetivos e demarcar identidades.

\section{0 segundo $\mathrm{H}$ : um país em crise permanente}

O leitor deste início de milênio está, ainda que superficialmente, familiarizado com o drama haitiano, que perpassa a música popular (no famoso refrão: “o Haiti é aqui”) e o noticiário 
televisivo. A presente crise haitiana (que se inicia explicitamente em 2004/2005) envolve de perto o governo brasileiro, que para lá enviou suas tropas, visando restabelecer (ao menos, em tese) a governabilidade e dar posse a um presidente democraticamente eleito. Esta é, no entanto, tão-somente uma penúltima reencenação de uma crise que se tornou estrutural naquele que é o mais pobre país das Américas, e um dos países mais pobres de todo o mundo, exceção feita a alguns países africanos.

Primeiro país nas Américas a tomar para si as rédeas do poder no âmbito de um processo acidentado de descolonização e abolição da escravatura, o Haiti, por razões que em muito ultrapassam meus conhecimentos (e intrigam os historiadores), se viu, desde então, às voltas com graves problemas políticos, econômicos e sociais. Brevemente, pode-se dizer que o país não conseguiu se industrializar ou mesmo estabelecer uma agricultura em bases modernas, vivenciou uma sucessão de ditaduras sangrentas e afundou em um ciclo sem-fim de conflitos sociais, que perpassam todo o tecido social (compreendendo desde a ação de pequenos bandos armados até conflitos de massa, nos moldes de guerras civis e guerrilhas).

Localizado em uma região de grande beleza natural e extremamente barato para o turista, especialmente norte-americano, que ganha em dólar (ou outra moeda forte) e mora próximo, o país se transformou numa Meca do turismo internacional, com o estabelecimento de um forte movimento pendular de turistas de várias nacionalidades, com marcante presença de turistas provenientes dos países vizinhos.

Em paralelo, devido a uma quadro de violência estrutural, desemprego e perseguição política, o Haiti se transformou em um exportador de mão-de-obra barata ou, antes, de pessoas 
desalojadas pelos diferentes conflitos locais. Vários dos imigrantes haitianos aportam nos diferentes países (especialmente nos EUA) nas condições mais precárias possíveis, e, com relativa freqüência, se inserem em redes ilícitas, trabalhando informalmente nas mais diversas (e mal pagas) ocupações, quando não perambulando em busca de alternativas de moradia e trabalho.

Retomando o fio da meada: foram estas inúmeras mazelas e flagrantes desigualdades que estabeleceram redes sociais fortemente interativas, que puseram em interação haitianos e norteamericanos. E assim como onde há fumaça... há fogo..., onde há interações marcadamente desiguais entre seres humanos, estabelecem-se circuitos de exploração sexual, sexo comercial, além de distância e mesmo ocultação deliberada face às instâncias formais, entre elas, a saúde pública e a medicina de um modo geral. Pessoas de quem é subtraída a cidadania não são donos de seus corpos, e os vendem no mercado do mundo. Não têm, igualmente, oportunidades de 'cuidar de si', às voltas com deficiências de transporte, falta de seguro social (ou dinheiro para pagar médicos particulares) e de tempo, que não seja o despendido na luta pela sobrevivência cotidiana (escapar da violência, ganhar a vida como for possível, comer...).

Tais condições de vida adversas, sejam elas as dos haitianos que permanecem no seu país de origem, sejam as dos imigrantes vivendo em condições precárias nas metrópoles norte-americanas, são degradantes para seres humanos, mas ideais para vírus, que, como disse repetidas vezes, almejam, antes e acima de tudo, persistir. E se o 'propósito' é persistir, haveria população mais facilmente 'parasitável' que esse amplo contingente de deserdados da terra, desnutridos, enfraquecidos por uma série de doenças (algumas delas, como diversas infecções sexualmente transmissíveis, 
capazes de facilitar a transmissão do HIV), extremamente móveis, inseridos em circuitos de interação sexual desprotegida, quando não em redes de tráfico e consumo de drogas.

Não é de estranhar que os haitianos se tornassem o segundo $\mathrm{H}$, numa tentativa conceitual tão simplista quanto certeira na sua capacidade de discriminar e estigmatizar. A despeito da evidente exploração sexual e de séculos de injustiças e violações de toda a sorte, os haitianos se tornaram uma categoria em si, supostamente afetada pela Aids devido a uma preferência velada do HIV... por haitianos!

\section{Mercadejando o sangue do mundo: o terceiro $\mathrm{H}$}

Quando se pensava que toda a crueldade do conturbado século XX havia atingido seu ápice com o holocausto e a bomba atômica, eis que emerge, já no apagar das luzes, uma nova forma de exploração do homem pelo homem - exploração não mais de seres humanos digamos 'integrais' (termo pouco apropriado para populações espoliadas, admito, mas não me ocorre outro, em contraposição ao que descreverei a seguir), mas de seus 'pedaços', como órgãos e fluidos.

Ainda que a expropriação e circulação de órgãos humanos pertença antes de tudo à crônica policial, aflorando aqui e ali, em histórias horripilantes, o sangue foi objeto, até há pouco no Brasil (e ainda o é, em diversos países), de um comércio não só explícito, como florescente.

Dado o caráter inovador e complexo dos processos biotecnológicos envolvidos na produção dos assim denominados 'hemoderivados' (ou seja, produtos biológicos derivados do sangue) constitui-se, no mundo contemporâneo, um circuito de produção e consumo de características monopolistas e exclu- 
dentes. Neste mercado humano, demasiado humano, cabe aos países em desenvolvimento exportar (como sempre ocorre), a commodity primária (o sangue) e importar, a preços substancialmente mais elevados, os produtos daí derivados, neste caso, os hemoderivados.

Numa reprodução, em menor escala, das desigualdades em escala global, no âmbito das sociedades nacionais, os assim denominados 'doadores profissionais' fornecem sangue, em troca de uma pequena compensação financeira. Esses doadores profissionais são (no Brasil, eram, pois tal prática foi proibida por lei, em meados da década de 1980), em sua imensa maioria, recrutados dentre os segmentos mais pobres e marginalizados de cada sociedade, congregando, por exemplo, mendigos (como mostrou um trabalho brasileiro realizado no período) e usuários de drogas injetáveis. Em se tratando de uma população vivendo em condições bastante precárias, não é de se estranhar que ela tenha taxas de infecção (pelo HIV e diversos outros agentes infecciosos) substancialmente mais elevadas do que a população de um modo geral (o que foi documentado por inúmeros trabalhos, realizados em diferentes países).

Pior: na produção de hemoderivados são utilizadas amostras de sangue provenientes de vários doadores visando à produção de um único lote de cada hemoderivado específico. Com isso, aumentam substancialmente as chances de que cada um dos lotes de hemoderivados inclua, ao menos, uma amostra de sangue contaminado.

Por essas razões, e pelo fato dos hemofílicos receberem determinado hemoderivado de forma repetida ao longo da vida, aumentam exponencialmente as chances de que um determinado indivíduo hemofílico seja infectado a partir de um produto 
que se origina de um extenso pool de doadores, estando um ou mais de um deles infectado pelo HIV e/ou outros patógenos de transmissão sangüínea.

Numa versão absolutamente perversa dos processos de globalização, milhares de hemofílicos e outros pacientes que haviam recebido transfusões sangüíneas no final da década de 1970 e início da década seguinte (quando ainda não se dispunha de testes sorológicos para o HIV) foram infectados pelo HIV. Ainda que considerados 'vítimas inocentes' de 'erros médicos', faltou compreender o essencial: não se trata de 'erros', mas sim de um desdobramento esperável de um mercado regido por uma lógica absolutamente distorcida.

No Brasil, sob a liderança de Herbert de Souza, o Betinho, e com a participação de diversos profissionais de saúde e ativistas, implementou-se, em meados da década de 1980, uma profunda reforma da legislação relativa a doações e à operação de bancos de sangue, com o fechamento de vários estabelecimentos que funcionavam em franca contradição com a legislação e as boas práticas laboratoriais. Infelizmente, no caso de Betinho, a mudança chegou tarde demais \% tendo (con)vivido por longos anos com a hemofilia e, posteriormente, a Aids, faleceu ele em decorrência de uma segunda infecção, a hepatite $C$, que igualmente contraiu a partir do sangue contaminado.

\section{Um falso quarto H: os usuários de drogas injetáveis}

Mesmo no âmbito de diversos equívocos e distorções, saltam aos olhos os erros e preconceitos referentes aos usuários de drogas injetáveis, que foram reduzidos a uma única modalidade de consumo por via injetável, a injeção da heroína - o 
quarto $\mathrm{H}$. Um dos equívocos mais curiosos neste caso refere-se à própria droga injetada. Possivelmente devido ao estigma longamente associado à heroína nos locais onde seu consumo é mais prevalente, como os Estados Unidos, Europa e Austrália, foi a ela conferida um papel indevido, por diversas razões.

Em primeiro lugar, a cena de uso de drogas na década de 1980 era bastante mais matizada do que se suponha a princípio, com a entrada em cena da cocaína (entre outras substâncias, que o presente texto não tematiza), sob várias apresentações (cheira$\mathrm{da}$, injetada, e, em um momento posterior, fumada, sob a forma de pedras de crack). A cocaína injetada estava bastante presente na cena de drogas nos Estados Unidos e Europa ocidental na década de 1980, quando foi formulado o conceito do quarto H, ou seja, uma ampla fração de usuários de drogas injetáveis, usuários de cocaína, isoladamente ou em combinação com a heroína (denominado speedball) foi simplesmente ignorada. O problema maior relativo a essa omissão é que ela excluiu do campo do HIV/Aids exatamente os usuários de drogas cujas taxas de infecção pelo HIV são mais elevadas, devido a uma série de fatores, que a pesquisa se encarregou de esclarecer posteriormente.

A primeira dessas omissões decorre de um erro fundamental em metodologia científica. Sabe-se, pelo menos desde Aristóteles, que é preciso observar os fenômenos e descrevê-los da forma mais acurada e exaustiva possível, antes de estabelecer inferências acerca deles. Caso as práticas dos usuários de cocaína injetável tivessem sido adequadamente observadas e descritas, saber-se-ia que seu padrão de uso (injeções repetidas em um curto intervalo de tempo, denominado em inglês binge, termo que não tem tradução exata para o português), está fortemente 
associado ao compartilhamento de agulhas e seringas (o elemento central da transmissão do HIV nesta população) e, com isso, à transmissão do HIV. Embora a documentação formal, do ponto de vista epidemiológico e estatístico, da estreita associação do binge e transmissão muito pronunciada do HIV date de 1991 (a partir de um artigo de pesquisadores da Universidade Johns Hopkins, EUA), já se dispunha, desde o início da década de 1980 (ou mesmo antes), de detalhados relatos sobre as práticas de injeção de usuários de diferentes drogas, a partir de trabalhos, informais, das próprias associações de usuários de drogas, como as Junkiebonden, algo como um 'sindicato' de usuários de drogas holandeses. Mas quem daria ouvido a um bando de 'doidões’? O preço da omissão se traduziu, como sempre, em sofrimento e mortes desnecessários.

Aos poucos, pesquisadores corajosos e inovadores, como o também holandês Jean-Paul Grund, e diversos pesquisadores norte-americanos, estabeleceram canais de comunicação com os próprios usuários de drogas, dedicando-se a levantar e sistematizar a rica etnografia das cenas de uso. Entre outras lições, esses pesquisadores demonstraram (a partir de um extenso conjunto de trabalhos de natureza etnográfica, epidemiológica e biológica) que, além do compartilhamento das seringas e agulhas utilizadas na auto-administração de drogas injetáveis, o compartilhamento dito 'indireto' dos demais materiais e equipamentos de injeção, como, por exemplo, o hábito de diversos usuários de drogas, especialmente, de cocaína, de preparar uma solução comum de cocaína, em que 'abastecem' e 'lavam' suas seringas individuais, estava igualmente associado à transmissão do HIV (em função do vazamento de restos de sangue contaminado, contido nas seringas, a cada rodada de abastecimento/lavagem). 
Aqui também o risco maior era o experimentado pelos usuários de cocaína (e não de heroína!), cujas práticas de preparação de solução de drogas envolvem recipientes cheios de solução de cocaína, em que seringas são repetidamente enchidas e esvaziadas, e, freqüentemente, 'graduadas' (ou seja, utiliza-se um recipiente ou seringa comum para abastecer as seringas individuais com doses específicas, de modo a evitar desperdício e minimizar o risco de sobredosagem - overdose). Ao contrário, os usuários de heroína injetam esta substância de forma mais espaçada no tempo, e lançam mão de acidificantes (como o limão) e fogareiros (ou equivalentes) no preparo, o que reduz substancialmente os riscos associados ao compartilhamento indireto. Enfim, por estas e outras razões, o quarto H é, na verdade, um $\mathrm{CH}$ (C de cocaína).

Finalizando essa breve incursão pelas cenas de uso de drogas, cabe observar que um dos elementos-chave do compartilhamento de agulhas e seringas (e, portanto, da disseminação do HIV nesta população) deve-se, paradoxalmente, à adoção de sucessivas legislações com vista a evitar o uso de drogas injetáveis. Obviamente, a legislação não é a única dimensão a ser abordada neste caso, inclusive porque em países em que ela jamais foi adotada (como o Brasil) observa-se também o compartilhamento de equipamentos de injeção. Não resta dúvida, entretanto, de que as leis que restringem a aquisição e o porte de equipamentos de injeção (que, em inglês, são conhecidas como prescription laws e paraphernalia laws, respectivamente) desempenham um papel fundamental no incremento das práticas de compartilhamento de agulhas e seringas, e, com isso, da transmissão do HIV e outros agentes infecciosos. Um interessante conjunto de trabalhos, que avaliou usuários de drogas 
diabéticos (que têm isenção frente às leis de controle da venda e porte de seringas, em função do eventual uso de insulina injetável) e não-diabéticos, registraram taxas de infecção substancialmente mais baixas entre os usuários diabéticos (frente aos demais), pareadas outras características, como idade ou padrões específicos de consumo de drogas.

\section{POR UMA CIÊNCIA RENOVADA}

Em todos os exemplos até aqui mencionados, a interação o mais possível livre de preconceitos e pautada no diálogo entre pesquisadores e pesquisados, quando não a pesquisa empreendida pelos próprios membros das comunidades mais atingidas, é capaz de renovar os surrados paradigmas e abrir novos horizontes, para além dos $4 \mathrm{H}$ e outras propostas igualmente simplistas e reducionistas.

Algumas das metodologias mais criativas e férteis de análise de processos de difusão - e toda a epidemia, é antes de tudo, um processo de difusão, no caso, de uma 'máquina spinoziana', que tudo 'faz' no sentido de maximizar esses mesmos processos de difusão - provêm de estratégias que compreendem o fenômeno de difusão, não da perspectiva exclusiva dos indivíduos, mas sim de suas interações e dos contextos em que se inserem. Se é verdade que a ampla maioria dos trabalhos da primeira metade da década de 1980 cometeu erros crassos, a partir do emprego sistemático do paradigma equivocado dos 'grupos de risco', isto não teve lugar em função de não se dispor de alternativas conceituais e metodológicas apropriadas, mas sim em função da adesão da ampla maioria de pesquisadores a lugarescomuns, e, por que não?, em decorrência da ignorância. 
Em 1985, o sociólogo norte-americano, radicado na Austrália, Alden Klovdahl, publicou um trabalho clássico em que descreve a aplicação da análise de redes sociais ao então emergente fenômeno da Aids. Os conceitos e diagramas de Klovdahl, que pareciam bizarros à época, acabaram por inspirar inúmeros trabalhos, com a defasagem de décadas (avaliando-se as citações deste trabalho fundamental, através da ferramenta de busca ISI - Web of Science, constata-se ter ela se transformado em um 'clássico contemporâneo', que desafia a tradicional obsolescência dos artigos científicos). Mas, afinal, quem ligava, à época, para um misterioso sociólogo australo-americano inteiramente à margem do establishment epidemiológico? 


\section{A Sociedade Reage... \\ 3 । As Contradições Persistem}

A crise da Aids emerge, nos países denominados ocidentais, em meio à emergência e hegemonia de governos conservadores. Na minha opinião, tal conceituação não deve ser estendida a contextos onde a epidemia era sabidamente grave, como o Haiti e diversos países da África subsahariana, onde igualmente predominavam, à época, governos conservadores, muitas vezes apoiados em ditaduras sangrentas, mas onde não existia (e continua não existindo, na maioria dos casos) alternância democrática ou um Estado de fato estruturado. Isso por dois motivos: nesses últimos países, em desenvolvimento, não se observou propriamente uma emergência de governos conservadores, nos marcos da alternância habitualmente verificável nas sociedades democráticas, mas sim uma hegemonia conservadora consolidada, atrelada a regimes autoritários, seja de direita ou de esquerda, que duravam décadas, sem alternância alguma do poder. Em segundo lugar, tais países, em meio a inúmeras crises estruturais, nem ao menos tiveram ou têm a chance de montar respostas efetivas às suas inúmeras crises de saúde, das quais a epidemia de Aids seria mais um elemento.

Portanto, esboço, a seguir, a história dos 'vencedores', explorando posteriormente a dos 'vencidos', mas segundo um outro paradigma, o das respostas que não ocorreram por falta de vontade política, diálogo com as respectivas sociedades, o apoio de um Estado minimamente estruturado e condições eco- 
nômicas que permitissem financiar de forma sustentável uma resposta à crise colocada pela Aids.

A década de 1980 se caracteriza pela emergência de governos e de uma agenda claramente conservadora, liderada por Ronald Reagan, nos EUA, e Margareth Thatcher, no Reino Unido. Ao contrário de episódios anteriores, a consolidação da agenda conservadora de então ocorreu em um mundo francamente interdependente, fazendo com que os países periféricos dispusessem de uma margem de manobra mínima, tanto do ponto de vista econômico (o que veio a constituir a hegemonia das políticas econômicas ditas neoliberais), como social e político. Ou seja, a reemergência da agenda conservadora teve lugar em um mundo globalizado em uma escala até então inimaginável. Apenas a título de exemplo, as políticas de drogas de todos os países se viram atreladas à assim denominada 'guerra às drogas', empreendida pelo governo norte-americano. Com isso, as políticas públicas mais avançadas no campo das políticas de drogas (por exemplo, descriminalização do consumo das drogas ditas 'leves') ou das políticas públicas referentes à sexualidade e reprodução (como a realização de abortos dentro dos marcos legais e amparados pelo sistema público de saúde) foram formuladas por governos e sociedades em oposição aberta a forças políticas hegemônicas no nível mundial e se depararam, por isso mesmo, com formidáveis resistências e recursos minguados ou de todo ausentes.

A crise da Aids, na sua estreita associação com temas tabus para qualquer agenda conservadora, como o homossexualismo ou o consumo de drogas, confrontou os governos conservadores com dilemas complexos, enfrentados por eles, o mais das vezes, por meio de negação, protelação, e, 
em uma etapa posterior, debates ásperos, quando não conflitos explícitos.

Retomando o raciocínio desenvolvido no capítulo anterior, é possível supor que o movimento inicial de negação se apoiava na desqualificação da Aids como questão de saúde pública, seja através da sua 'insulação' a 'alguns pequenos grupos de indivíduos com hábitos bizarros', seja por intermédio de uma redução (deliberada ou ingênua) da sua magnitude e escopo. Reiterados pronunciamentos das autoridades de então afirmavam ser a Aids um problema exclusivo das comunidades gays, ou dos haitianos, ou de..., até que a enumeração se tornou por demais exaustiva e abrangente, a ponto de descaracterizar as exceções enquanto tais.

Talvez a fala mais cruel, dentre tantas, tenha sido aquela dirigida aos usuários de drogas por um político conservador, que certa vez afirmou que a "Aids traria a 'cura' para o consumo de drogas, com a eliminação mútua de uns e outros - usuários de drogas e pessoas vivendo com Aids".

Filmes e livros como And the Band Played on: politics, people, and the Aids epidemic (1987), do escritor e ativista norte-americano Randy Shilts, documentam as inúmeras hesitações e conflitos que permearam a sociedade norte-americana de então. Não é necessário aqui, portanto, repisar essas dificuldades e indecisões, mas, sim, recuperar as iniciativas exitosas da sociedade civil ao arrepio dos governos e, por vezes, das legislações nacionais.

Diversas comunidades particularmente afetadas implementaram campanhas preventivas boca-a-boca, sendo uma das mais bem-sucedidas a campanha desenvolvida por líderes da comunidade gay norte-americana e européia (grosso modo, multiplicadas por outras comunidades gays mais estruturadas, em países com 
renda e desenvolvimento intermediários entre as nações desenvolvidas e as nações em desenvolvimento, como é o caso das iniciativas brasileiras). Com o sacrifício da precisão em prol da concisão, é possível resumir essas iniciativas a partir de alguns marcos conceituais:

1) valorização das iniciativas e do conhecimento acumulado das próprias comunidades mais diretamente afetadas;

2) interlocução com os poderes públicos, sem que isso significasse subalternização ou cooptação das lideranças comunitárias, combinando crítica construtiva e ação conjunta, nos casos em que isso fosse possível e desejável;

3) utilização simultânea de recursos da grande mídia (incluindo a realização de campanhas e levantamento de recursos em grande escala) e de canais informais e de pequena escala, seguindo estes últimos os canais habituais de comunicação e debate das próprias comunidades afetadas;

4) 'publicização' da condição de pessoa vivendo com HIV/Aids como estratégia de combate ao preconceito e estigma, valorização das singularidades e defesa dos direitos civis e compartilhamento de vivências;

5) estabelecimento de redes de disseminação de idéias, debate e oferta/intercâmbio de ajuda material, psíquica e espiritual-religiosa;

6) valorização da solidariedade, altruísmo, comprometimento com a esfera pública e a dimensão comunitária da crise colocada pela Aids, enfatizando transparência das ações;

7) promoção de mensagens claras de prevenção, como a campanha do sexo mais seguro; 
8) busca de novas alternativas de tratamento e prevenção, num diálogo crítico com os avanços da ciência, e a tradução desses avanços em produtos e iniciativas concretas.

Aprofundo, a seguir, os dois últimos itens, na medida em que ambos tocam em questões nevrálgicas, ainda por serem desatadas.

Em primeiro lugar, cabe esclarecer um ponto aparentemente bizarro e destituído de qualquer relevância, mas que tem alimentado polêmicas tão exaltadas como inúteis. Trata-se da curiosa perda de um R, que, entretanto, muda, a meu ver, completamente o sentido das campanhas iniciais em prol do sexo mais seguro (em inglês, safer). $\mathrm{Na}$ sua versão original da proposta, utilizava-se o termo safer, ou seja, mais seguro, 'mais seguro' em realação à prática do sexo sem proteção, ou seja, sem a utilização de condoms ('camisinhas'). A perda do R transforma tal conceito em algo insustentável, em um suposto sexo 'seguro', uma proposta absolutizante que não encontra correspondência na vida real, em nenhuma esfera da vida humana, pois, como dizia Guimarães Rosa, "viver é muito perigoso". Não se trata de modo algum de uma questão restrita ao sexo ou à sexualidade, muito pelo contrário; na verdade, nada, na esfera da vida, é absolutamente seguro, portanto, não haveria porque sê-lo em se tratando de sexo ou qualquer outra atividade humana.

Um dos exemplos clássicos nesse sentido é a ingestão de água, atividade trivial, mas de forma alguma isenta de riscos. Embora a ingestão de água em excesso apresente um risco desprezível na vida cotidiana, o relativamente recente advento do ecstasy emprestou ao prosaico ato de beber água um significado ritual e um risco. A maioria das mortes observadas entre pessoas 
que freqüentam festas dançantes (raves) e ingerem água de modo desmedido após tomarem um ou mais comprimidos de ecstasy se dão exatamente por intoxicação hídrica (cujo mecanismo subjacente ultrapassa os propósitos do presente texto), ou seja, uma morte por excesso de água no organismo.

Portanto, qualquer idéia de um sexo absolutamente seguro esbarra no contra-senso de uma certeza absoluta em um mundo de incertezas e probabilidades. Portanto, a eterna polêmica entre religiosos e não religiosos em torno da segurança supostamente absoluta dos preservativos me parece totalmente fora de foco. Não é atacando ou defendendo a suposta infalibilidade da 'camisinha' que se chegará a qualquer conclusão proveitosa; a questão que se coloca aí é o acerto ou desacerto do dogma religioso em si com relação às políticas públicas de estados laicos, não o acerto ou desacerto (pois, obviamente, trata-se de um desacerto) de um hipotético dogma da infalibilidade dos preservativos. Cabe assinalar aqui que para alguns agentes infecciosos, como o Papiloma Vírus Humano (agente causal do câncer uterino e outros tumores), ao contrário do que ocorre com o HIV (em que os preservativos constituem proteção bastante eficaz e efetiva), a 'camisinha' não representa uma barreira de proteção eficaz, pois este vírus (diferentemente do HIV, repito) pode permanecer na base do pênis ou na região perigenital, de homens e mulheres, sendo a transmissão 'extracamisinha' (por fora da área de proteção do preservativo) do vírus bastante bem documentada.

Em suma, o que se deve discutir é a redução, e não a eliminação, dos riscos associados ao sexo desprotegido. Retornando a uma afirmação do primeiro capítulo, os vírus nos precederam neste mundo, vasto mundo, permeiam e perpassam toda a nossa 
vida e, muito provavelmente, nos sobreviverão caso venhamos a desaparecer como espécie.

Finalizando esta questão, cabe registrar que a discussão conceitual em torno de alternativas 'mais seguras' se torna ainda mais confusa e imprecisa em se tratando do conceito de 'redução de danos' aplicado ao consumo de drogas. Ainda uma vez é possível falar em alternativas 'mais' seguras, mas de todo absurdo falar em alternativas 'seguras'.

Por definição, a aplicação injetável (especialmente intravenosa, a mais comumente empregada pelos usuários de drogas injetáveis e aquela que está mais freqüentemente associada a riscos e danos) de qualquer substância sempre envolve algum risco/dano, o que compreende desde eventuais lesões no próprio local da aplicação até reações que dependem da natureza do produto administrado, compreendendo irritação local, reações alérgicas, podendo chegar a complicações eventualmente sérias como as tromboembolias (formação de coágulos no sangue e seu deslocamento para outros locais, com conseqüente entupimento de vasos e lesão de tecidos e órgãos). A par dos efeitos adversos associados às características da própria substância, há que considerar efeitos eventualmente associados a contaminantes (de natureza biológica ou inorgânica), podendo gerar complicações infecciosas e não infecciosas, tais como a já mencionada tromboembolia, abcessos (feridas locais), flebite (inflamação das veias) e mesmo complicações infecciosas graves, como a endocardite (inflamação da membrana interna do coração, devido a irritantes químicos e diversos microrganismos, como vírus, fungos e bactérias).

Por essas razões, a aplicação de medicamentos por via injetável compreende a observância de normas estritas de biossegu- 
rança, tanto com relação ao produto (que deve ser submetido a rigoroso controle de quantidade) como ao aplicador (devidamente treinado e certificado, como no caso de profissionais qualificados de farmácia, enfermagem e medicina).

Obviamente tais considerações não se aplicam à auto-administração de substâncias de venda e uso ilícito, que não estão submetidas a qualquer controle, são objetos de misturas imprevisíveis (a depender das decisões dos traficantes) e são aplicadas pelo próprio usuário de drogas ou pessoas da sua rede de relações. Portanto, a idéia de uma auto-aplicação 'segura' de drogas ilícitas é absolutamente despropositada.

Do mesmo modo, o conceito a ser utilizado neste caso é o de 'redução', e não 'eliminação' de danos (e riscos), uma vez que a eliminação dos riscos e danos associados ao uso de drogas injetáveis só existe nos marcos do não-uso de drogas injetáveis. Portanto, quem jamais fez uso dessas substâncias, não está, sob este aspecto, sujeito a risco específico algum ou sujeito a dano algum diretamente associado a este comportamento, da mesma forma que uma pessoa que jamais andou a cavalo não pode sofrer um acidente devido à queda de um cavalo. Obviamente, não é a estas pessoas que deve se dirigir uma eventual campanha para reduzir os males associados a andar a cavalo de forma imprudente, a não ser no sentido de desestimular que pessoas não familiarizadas com cavalos o façam sem se cercarem antes das devidas precauções.

Mas as ações que denomino anteriormente de 'redução de danos' se destinam a pessoas que em determinado momento de suas vidas não querem e/ou não são capazes de interromper seu consumo de drogas. Neste caso, sim, cabe oferecer alternativas de tratamento e apoio psicossocial (não necessariamente bem 
recebidas pelo eventual beneficiário). Caso isso não seja possível em determinada circunstância (por exemplo, por recusa do potencial beneficiário), o que é bastante comum, cabe oferecer a estes indivíduos alternativas que lhes permitam correr menos riscos e experimentar menos danos decorrentes do seu consumo, e não abandoná-los à sua própria sorte, correndo diversos riscos, inclusive o de se infectar com o vírus da Aids e outros vírus, fungos e bactérias transmissíveis pelo sangue.

Retomando a lista de itens já mencionados, enfoco agora a complexa e contraditória inter-relação entre formulação de alternativas de intervenção e a agenda da academia e dos governos nacionais.

Com disse anteriormente, face às contradições e hesitações dos governos dos países centrais, como os Estados Unidos, o protagonismo no enfrentamento da epidemia de Aids nos países desenvolvidos coube às próprias comunidades mais diretamente afetadas, como a comunidade gay norte-americana e européia. A resposta dessas comunidades foi vigorosa e bem-sucedida devido a razões diversas, entre elas, a sua capacidade de mobilização, a eficiente exploração dos canais de comunicação e redes já existentes e à pressão que suas lideranças exerceram sobre fontes de financiamento e governos. O que se seguiu foi uma combinação de diálogo e confronto, sempre caminhando no fio da navalha entre a incorporação das iniciativas à agenda das agências de fomento e governos, e os riscos, por um lado, de quebra do diálogo, e, por outro, de cooptação de ativistas pelos governos e agências. O campo do desenvolvimento e acesso a novos medicamentos retrata uma das facetas mais tensas dessas interações entre sociedade civil, empresas, agências financiadoras, governos e suas agências reguladoras, e vou abordá-lo 
logo a seguir. Antes, porém, farei uma breve, mas tensa, incursão pelas estratégias preventivas dirigidas aos usuários de drogas injetáveis.

Assim como ocorreu com as comunidades gays nos EUA e Europa, a reação dos usuários de drogas começou, não a partir da iniciativa de governos ou agências, mas sim a partir dos próprios usuários de drogas, população que, até então, todos julgavam incapaz de se mobilizar em defesa dos seus próprios interesses (a exceção, que até então confirmava a regra, eram os grupos de mútua-ajuda, que, no entanto, de acordo com seus princípios básicos, atuam sempre de forma anônima e longe de qualquer ativismo ou proselitismo).

Exceção feita a uma iniciativa logo abortada de distribuir seringas estéreis na Escócia, em uma inovadora, mas fugaz, parceria entre usuários de drogas e proprietários e empregados de uma farmácia no início da década de 1980, é possível definir a iniciativa das associações ou sindicatos de usuários holandeses (Junkiebonden), anteriormente mencionados neste livro, como o marco zero dessas propostas. Ao contrário do que a maioria das pessoas pensa, a idéia desse curioso sindicato de usuários de drogas de trocar seringas (usadas, e potencialmente contaminadas, por seringas novas/estéreis) não estava originalmente relacionada à epidemia de Aids, mas sim a uma ameaça percebida à época como mais concreta, a hepatite. Como todo sindicato que se preze, também as Junkiebonden se pautavam em resultados concretos e não em sutilezas acadêmicas, e nada mais concreto naquela ocasião do que uma epidemia de hepatite que vinha acometendo os usuários de drogas de Amsterdã (posteriormente foram evidenciadas duas epidemias concomitantes, pelas hepatites $\mathrm{B}$ e C). 
O sucesso dos então denominados Programas de Troca de Seringas (PTS) holandeses fez com que as primeiras estratégias de prevenção dirigidas à nascente epidemia de Aids entre usuários de drogas injetáveis implementadas por organizações nãogovernamentais (ONGs) e, depois, pelos governos locais (como prefeituras e administrações regionais), em outros países da Europa, além da Holanda, e Austrália, tivessem nos PTS um dos seus principais eixos de atuação.

Daí em diante, estes programas, ainda que tivessem estrutura e propósitos em tudo similares nos diferentes contextos, tiveram destinos os mais diversos, quando não francamente contrapostos. Na Austrália, os PTS se tornaram rapidamente uma política pública e uma ação central na proteção da saúde pública, integrante do elenco de políticas públicas dos estados e territórios australianos, e, pouco depois, do governo federal daquele país. Em um desdobramento natural da incorporação dos PTS às políticas oficiais australianas, verbas federais foram alocadas tanto em projetos desenvolvidos por órgãos oficiais, como também em ONGs de natureza diversa, incluindo as organizações coordenadas por associações de usuários de drogas. O sucesso dessas e outras iniciativas (como a ampliação e flexibilização da oferta de tratamento) fizeram com que a epidemia australiana jamais atingisse de forma relevante a população de usuários de drogas injetáveis (e seus parceiros sexuais), no que o pesquisador norte-americano Don des Jarlais e colaboradores denominariam "epidemias prevenidas".

A sorte dos PTS seria inversa nos EUA, onde estes programas se iniciam pela implementação de um pequeno programa na localidade de Tacoma, Washington, costa oeste dos EUA. A designação deste programa, cunhada por seu idealizador, o ativista 
David Purchase, Point Defiance (algo como Ponto de Resistência/Oposição), traduz o clima de verdadeira beligerância que esses programas enfrentaram e enfrentam até hoje nos EUA, tanto fomentado por forças locais, como pela ativa oposição dos governos estaduais e do governo federal. A forte oposição local acabou sendo (como diversos outros fenômenos sociais no mundo anglo-saxônico) conhecida através da definição de uma síndrome, dita síndrome Nimby, um acrônimo de Not in my backyard, ou, em bom português, 'Não no meu quintal', refletindo a idéia e a experiência concreta de que as comunidades, via de regra, não querem na sua vizinhança imediata (denominada aqui quintal) a instalação de quaisquer programas ou projetos dirigidos a grupos considerados 'desagradáveis’ (e poucos grupos, em todo o mundo, são tão malvistos como os usuários de drogas). O erro desse raciocínio, além da óbvia questão ética de negar assistência a um segmento populacional, já, de antemão, marginalizado e criminalizado, é que a combinação de populações marginalizadas, estigmatizadas e mal assistidas, e a ação violenta das gangues e das instâncias repressivas constitui o fermento da desordem urbana e da violência estrutural. Basta comparar a espiral de violência de nossas favelas ou dos bairros 'guetificados' de cidades como Los Angeles, EUA, com a situação inegavelmente problemática, mas não abertamente violenta e conflituosa, que caracteriza os bairros onde se concentram os usuários de drogas e outras populações marginalizadas no norte da Europa (o que posso testemunhar, pois lá morei) ou Canadá (o que também pude testemunhar de perto).

Mas a oposição norte-americana aos PTS e iniciativas similares é, antes de tudo, a oposição dos grupos de opinião e lobbies 
de extração religiosa e grupos conservadores de um modo geral, com vigorosa atuação na administração federal norte-americana, o que fez com que o governo democrata de Bill Clinton não conseguisse revogar a proibição federal (federal ban) de financiar os PTS, o que, evidentemente, só se acentuou nas duas gestões republicanas subseqüentes (governo George W. Bush). Até hoje, os programas norte-americanos têm sido financiados como 'projetos de pesquisa' das diferentes universidades ou a partir de iniciativas exclusivamente locais. A despeito das sucessivas avaliações positivas desses programas por parte das mais diferentes instituições de pesquisa norte-americanas (como o renomado Instituto de Medicina, um dos órgãos que compõem o conjunto de instituições científicas que os norte-americanos denominam The National Academies), não existe qualquer perspectiva de mudança no âmbito da administração federal norte-americana no que diz respeito aos PTS, no que o pesquisador e ativista Peter Lurie denominou: "a colisão entre ciência e política".

No Brasil, após um início conflituoso, quando não de confronto aberto com as instâncias jurídicas e policiais, os PTS foram implementados como iniciativas locais (inicialmente, em Salvador, Bahia), e, imediatamente depois, como iniciativas apoiadas pelo Ministério da Saúde. Ainda que tais programas enfrentem até hoje problemas, tais dificuldades são antes fruto dos problemas crônicos de gerência e financiamento continuado das mais diferentes iniciativas de saúde no Brasil, do que da oposição estruturada de quaisquer forças políticas ou sociais.

Ao contrário do relativo êxito das iniciativas brasileiras neste campo, em certos contextos, o conflito de opiniões e mesmo o confronto explícito entre as propostas e iniciativas de pesquisadores, profissionais de saúde e ativistas, face às normas e ações 
do aparato jurídico-policial pode ser áspero e persistente, a ponto de paralisar a resposta de toda uma sociedade.

Uma análise particularmente informativa acerca da inter-relação entre as diferentes iniciativas e forças sociais mencionadas anteriormente é a da disseminação do HIV/Aids nas repúblicas que integravam a União Soviética, e que hoje constituem diferentes países, como a própria Rússia, a Bielo-Rússia, a Letônia, a Lituânia, a Ucrânia etc.

Estes países vivenciaram uma confluência de problemas e conflitos com o fim do bloco soviético como um todo e da União das Repúblicas Socialistas Soviéticas (URSS), especificamente. A região, após o colapso do comunismo, mergulhou numa crise sem precedentes, que poderia ser subdividida (com finalidades didáticas, já que, de fato, há uma profunda imbricação entre as diferentes dimensões da crise) numa crise de liderança política e dos respectivos projetos nacionais, numa crise intergeracional e numa profunda crise econômica. A cada uma dessas dimensões correspondem diversos desdobramentos no campo da saúde pública e, mais especificamente, no campo do HIV/Aids.

A crise econômica, somada ao desmantelamento do sistema público de saúde (tanto no que diz respeito às ações preventivas como à rede de cuidados, compreendendo desde postos de saúde até hospitais) determinou uma reversão, inédita em todo o século XX (ainda que considerando os diferentes pós-guerras), dos padrões de morbi-mortalidade para níveis vigentes no início do século XX, exemplificado na queda dramática da expectativa de vida dos cidadãos russos, de valores próximos a 70 anos, para algo próximo a 45-50 anos, a depender da região e estrato populacional. Ao contrário de outras crises de saúde, o 
'declínio do império soviético' arrastou consigo as mais diferentes faixas etárias e grupos sociais, compreendendo desde um aumento brutal da mortalidade infantil a um aumento expressivo da criminalidade e violência, compreendendo ainda, entre outras questões, uma epidemia de tuberculose (em parte, com bacilos resistentes a múltiplos medicamentos) e as conseqüências adversas do abuso massivo de bebidas alcoólicas, como as hepatites e a cirrose hepática.

Ou seja, é como se no intervalo de uns poucos anos (início da década de 1990), todas as conquistas de décadas no âmbito da saúde pública tivessem, parafraseando o próprio Marx, se 'dissolvido no ar'.

A África subsahariana também experimentou, em decorrência da epidemia de Aids, uma reversão dos seus indicadores de saúde, com redução importante da expectativa de vida, embora, numa escala menor, mas ainda mais cruel, do que a verificada nas repúblicas das URSS, devido a duas diferenças fundamentais: a expectativa de vida (e outros indicadores de saúde) jamais havia atingido, na África subsahariana, padrões minimamente comparáveis aos padrões soviéticos (portanto, havia menos a perder, na vigência de mais uma, de uma longa lista de crises econômicas e de saúde pública). Da mesma forma, os países da África subsahariana jamais contaram com um sistema de saúde pública, de fato, abrangente e integrado, portanto, a inegável sobrecarga determinada pela epidemia de Aids (e os sobressaltos políticos que se arrastavam por décadas nas diversas regiões e países da África) não tiveram o efeito devastador de uma mudança política abrupta, incidindo sobre um sistema de saúde que, desde a Segunda Guerra Mundial, não se deparava, como o sistema de saúde soviético, com crises dessa magnitude. 
À crise econômica e ao colapso do sistema de saúde, somou-se uma crise de valores e projetos, com um forte componente intergeracional, opondo pais (educados segundo os rígidos padrões da era comunista) e filhos (educados em um momento de perda de referência e colapso dos diferentes sistemas sociais como: saúde, educação, estrutura de ocupação e trabalho etc.).

Numa economia subitamente erodida pela extinção de unidades produtivas e pelo desemprego formal, emergiram máfias e redes de circulação ilícita de mercadorias, entre elas: drogas, armas, dólares, e mais, pessoas, com a prostituição de adultos e crianças, de ambos os sexos.

O tráfico de drogas assumiu proporções não apenas imensas, como inéditas, uma vez que combinava, de forma inusitada, padrões ocidentais (de um mercado capitalista de drogas, com cartéis, como no mercado colombiano) a um mercado de natureza artesanal (com unidades domésticas de produção e refino), além de relações conturbadas com países produtores de ópio (matéria-prima da heroína), que a antiga URSS havia invadido, e que estavam, à ocasião da queda do bloco soviético, sob o controle dos seus antigos inimigos, os fundamentalistas muçulmanos do Talibã (com marcada influência sobre a Chechênia, que permaneceu, contra a vontade, como parte da nova Rússia). Ou seja, uma combinação de males de diversa extração e lógica operacional, fomentando tráfico, corrupção, chacinas, e, como não poderia deixar de ser, a disseminação do HIV.

Não por acaso, a disseminação do HIV na Rússia e ex-repúblicas soviéticas se deu, em determinadas populações (como os usuários de drogas injetáveis), numa velocidade e intensidade nunca antes vistas. Da mesma forma, iniciativas até então bem- 
sucedidas, como os PTS, se mostraram pouco ou nada efetivas no contexto da explosiva epidemia das ex-repúblicas soviéticas, em função do caos vigente nos mais diferentes setores e devido a fatores bastante específicos, como o fato do mercado artesanal de drogas vender preparados rústicos à base de opiáceos (derivados do ópio) em seringas pré-prontas. Com relação às seringas pré-prontas, de nada adianta trocar seringas usadas por novas (estéreis), pois os usuários injetam, quase sempre em grupos (para amortizar os custos), com a seringa cheia do preparado (de baixíssima pureza, por isso, mesmo consumido em largas doses e associado a overdoses, flebites, endocardites etc.) e não com seringas individuais, supostamente estéreis.

O colapso da saúde pública e a disseminação acelerada do HIV/Aids na antiga União Soviética constituem o documento mais vívido das profundas imbricações entre os diferentes níveis de determinação das epidemias e da vulnerabilização conjunta de indivíduos, comunidades e sociedades inteiras.

No outro lado do mundo, paradoxalmente similar ao seu antípoda soviético, o império norte-americano também se via, então, às voltas com uma nova epidemia, a disseminação maciça do crack nos seus guetos étnicos afetados pela violência estrutural: desemprego, ausência de seguro de saúde (problema que atinge hoje 40 milhões de norte-americanos), trabalho mal-remunerado de imigrantes ilegais e racismo. Neste caldeirão de problemas, o crack emergiu como uma alternativa barata, extremamente eficiente (do ponto de vista da obtenção de efeitos psicoativos intensos) e de fácil transporte e ocultação (sob a forma de pequenas pedras). Associado ao uso do crack (habitualmente fumado, mas, mais recentemente, e, cada vez mais freqüentemente, injetado, após acidificação) disseminou-se uma 
verdadeira 'onda' de sexo comercial rápido, quase invariavelmente sem o uso de preservativos, com múltiplos parceiros, em troca de dinheiro, favores diversos ou das próprias pedras de crack, com múltiplos, por vezes, sucessivos parceiros. As legiões de destituídos e os operadores do nascente mercado de venda e consumo de crack passaram a se congregar nas assim denominadas crack houses misto de lucros fáceis, criminalidade e disseminação de doenças infecciosas, inicialmente, a sífilis, e, logo depois, o HIV/Aids.

Cidades como Baltimore, no estado norte-americano de Maryland, que contam com um expressivo contingente de indivíduos de diferentes minorias étnicas (negros, hispânicos e outros imigrantes ilegais) e uma proporção expressiva de desempregados e subempregados, chegaram a ter níveis de prevalência de sífilis entre seus usuários de crack e parceiros sexuais comparáveis às taxas observadas na África subsahariana, num fenômeno de globalização da criminalidade e da pobreza, que constitui como uma contraface (inevitável?) da globalização triunfante das grandes corporações.

\section{OS PROGRESSOS DA TERAPIA}

Seria injusto terminar este capítulo sem mencionar explicitamente os inegáveis avanços científicos que desembocaram no anúncio, em 1996, pelo pesquisador David Ho e sua equipe, dos imensos benefícios decorrentes do emprego da combinação de diferentes medicamentos com propriedades anti-retrovirais (ou seja, que combatem o retrovírus HIV), no tratamento da infecção pelo HIV/Aids. Esta combinação, popularmente conhecida como coquetel, se por um lado, não trouxe, por ora, a tão sonhada cura, pôs por terra uma série de mitos sobre a Aids e determinou benefícios inegáveis para os pacientes infectados 
e/ou vivendo com a síndrome clínica (Aids), em termos de um aumento muito expressivo de sua sobrevida e uma melhora muito pronunciada da sua qualidade de vida. Pessoas que até então se debatiam bravamente contra o horizonte sombrio de uma morte anunciada, puderam retomar plenamente suas vidas, sob os mais diferentes aspectos, desde o afetivo-sexual ao profissional e social. Não que os ativistas e pessoas vivendo com Aids não procurassem até então viver vidas plenas de significado e sentido. Mas, não resta dúvida de que sua coragem ia sendo, pouco a pouco, desafiada por uma série de infecções (ditas oportunistas), emagrecimento progressivo e debilitação da resistência e capacidade de desempenhar as tarefas cotidianas. O coquetel agiu, no plano simbólico, como as poderosas armas que materializam a coragem dos heróis, como a Excalibur do Rei Arthur ou as armaduras e lanças dos seus cavaleiros.

Um dos mitos mais persistentes até então era de que não era possível reconstituir as funções do sistema imunológico, uma vez que essas funções estivessem comprometidas pelo contínuo ataque movido pelo HIV. O sistema imunológico que emergiu da era pós-coquetel ou pós-Haart (se utilizarmos a sigla acadêmica Highly Active Anti-Retroviral Therapy) se mostrou bastante mais dinâmico e flexível do que até se supunha (embora vozes dissidentes, como as do imunologista americano-israelense Irun Cohen, já encarassem há muito o sistema imunológico neste diapasão mais moderno e dinâmico). Fato é que, livre, por algum tempo, dos ataques à sua integridade empreendidos pelo HIV, o sistema imunológico se mostrou plenamente capaz de recompor sua estrutura e função, com uma redução e mesmo eliminação das doenças secundárias à sua fragilização (denominadas oportunistas). Livres, em grande medida, dessas doenças e de 
diversos cânceres (que igualmente emergiam e se disseminavam rapidamente em um organismo debilitado), as pessoas vivendo com Aids puderam retomar suas vidas cotidianas, sem os sobressaltos dos sucessivos episódios de doença.

O desafio maior da era pós-Haart é transformar a terapia em uma medida efetiva de saúde pública, ou seja, um recurso vital que chegue exatamente aos que dele mais necessitam. A despeito de sucessivas iniciativas de diferentes instituições internacionais e do esforço de ativistas, profissionais de saúde, gestores de sistemas de saúde e fundações privadas no sentido de ampliar o acesso à terapia nos países em desenvolvimento, ainda há um caminho imenso rumo a um mínimo de justiça e eqüidade de acesso ao tratamento. Em praticamente todo o mundo em desenvolvimento, e de forma particularmente na África subsahariana, demandas imensas, da ordem de milhões de pessoas, se contrapõem a uma oferta ainda bastante restrita dos diferentes medicamentos anti-retrovirais (correspondendo a algo como $10 \%$ da demanda).

A ciência fez, por assim dizer, o seu dever de casa, ao obter um conjunto de medicamentos extremamente potentes e efetivos, cabendo aos governos e principais atores sociais e econômicos tornar os frutos da ciência acessíveis à grande massa de deserdados da terra (na expressão de Franz Fanon). Se valerem os exemplos de outros recursos/insumos essenciais, menos complexos do ponto de vista tecnológicos e menos dispendiosos, como os sistemas de canalização de água potável e escoamento de detritos e dejetos, nada será conseguido se não com a pressão política e o altruísmo de diferentes pessoas com relação ao bem-estar público e ao respeito aos direitos humanos fundamentais, como o direito à vida em condições dignas. 


\section{Haiti Não É Aqui: \\ 4 IVIVER MAIS E MELHOR}

Ainda que a letra de Caetano Veloso tenha razão quanto à degradação urbana, a corrupção e a violência no Brasil e no Haiti, em se tratando de Aids, é possível dizer que o Haiti não é aqui. A partir de uma longa trajetória de militância política e da reforma do setor saúde e da ampliação do diálogo com a sociedade civil (ao menos, quanto a aspectos específicos, no que se inclui a prevenção e tratamento do HIV/Aids), o Brasil foi o primeiro país em desenvolvimento a instituir a terapia anti-retroviral potente (conhecida como 'coquetel' e na literatura científica como Haart, como visto no capítulo anterior), em larga escala e a custo zero (sob a perspectiva do consumidor final $\bullet$ paciente vivendo com Aids).

Portanto, o pesquisador ou profissional de saúde que escreve da perspectiva cotidiana do seu trabalho no Brasil, pode se considerar um privilegiado frente ao enorme contingente de pessoas vivendo com HIV / Aids em todo o mundo em desenvolvimento, que corresponde a mais de $90 \%$ das pessoas vivendo com HIV/Aids em todo o mundo, hoje, que, em sua esmagadora maioria, não se beneficiam, em nada, dos avanços mais recentes da pesquisa biomédica neste campo, e ainda sofrem e morrem, precocemente, como se vivessem (e morressem) na década de 1980.

Por uma questão de coerência frente à imensa massa de pacientes desassistidos e de impacto da epidemia numa perspectiva 
global, inicio este capítulo com os desdobramentos mais recentes da epidemia na África subsahariana e regiões da Ásia, onde a epidemia segue um curso acelerado e os pacientes já afetados pela síndrome clínica continuam a experimentar seus efeitos como se as quase três décadas de pesquisa em HIV/Aids tivessem redundado em um absoluto fracasso.

A África subsahariana tem sido a região mais devastada pela Aids (e por inúmeros outros males, como a desnutrição, e doenças endêmicas, como a malária) ao longo desses mais de 25 anos da epidemia visível, e um número difícil de precisar de anos de epidemia silenciosa (ou seja, na pré-história da Aids nos seus marcos ocidentais, como visto nos capítulos anteriores). A história da epidemia de Aids neste continente, que a imprensa passou a denominar "continente esquecido", reúne algumas poucas histórias de sucesso, como a de Uganda, onde a disseminação do HIV arrefeceu, e muitas histórias de inércia e negligência.

O eixo dinâmico da epidemia subsahariana deslocou-se, progressivamente, para o sul do continente, sem que a epidemia experimentasse qualquer sinal de reversão na porção mais central da África subsahariana ao longo dos anos, com algumas poucas exceções, como a de Uganda, já referida.

A epidemia da extremidade sul do continente africano atingiu proporções dramáticas nos países mais ricos do continente, África do Sul e Botswana. Especialmente na África do Sul, país bem mais populoso, a epidemia vem dizimando comunidades inteiras como na província de KwaZulu-Natal, habitada, em sua maioria, pelos Zulus, uma das etnias e grupos lingüísticos negros, que dividem com a minoria branca de ascendência holandesa e inglesa, um país atravessado por conflitos étnicos e injustiças sociais. 
A despeito de contar com a mais vigorosa indústria mineradora de todo o mundo, além de outras fontes de riqueza, como um comércio pujante e um setor de serviços (turismo, informática, pesquisa universitária) que exerce uma inconteste liderança em todo o continente, a resposta sul-africana segue sendo tímida e contraditória. Tendo visitado o país em 2000, tive o desprazer de ouvir suas então lideranças políticas criticarem abertamente as iniciativas de ampliação do acesso às medicações para tratamento da Aids, no que me soou como uma combinação de ignorância e cinismo, pois combinava argumentações científicas despropositadas sobre não ser o HIV a causa da Aids, com um aparente desprezo das recém-empossadas lideranças negras (cabe ressaltar que em oposição explícita a Nelson Mandela) pelo seu próprio povo.

Transcorridos seis anos da minha visita àquele país, só agora (meados de 2006) terei a oportunidade de rever, in loco, o impacto da epidemia sobre a população mais pobre (basicamente negra e mestiça) da África do Sul, ainda que todos os indicadores e reportagens veiculadas pela imprensa leiga dêem conta de um quadro ainda sombrio. De positivo, ao longo desses últimos anos, temos:

- A adoção da terapia anti-retroviral como medida profilática para grávidas que vivem com HIV/Aids, após acirrada batalha judicial, vencida, finalmente, pelos defensores da profilaxia medicamentosa para esta população. Ainda que os achados das pesquisas mais recentes expressem uma redução muito expressiva (para menos de $5 \%$ dos bebês filhos de grávidas infectadas pelo HIV) da transmissão mãe-bebê na população estudada, tais achados ainda estão basicamente restritos a estudos específicos, restando, portanto, a questão essencial de saber se esse impacto já se verifica 
de forma substancial na população como um todo, incluindo as mulheres que não têm acesso aos cuidados pré-natais ou de saúde de um modo geral ou mulheres que freqüentam o pré-natal de forma assistemática, além de outros problemas e dificuldades que emergem quando se tenta ampliar a escala de qualquer intervenção em um contexto de desigualdade social e acesso limitado aos cuidados de saúde.

- A implementação de amplos programas de saúde ocupacional, por parte das grandes mineradoras, em parceria com instituições sul-africanas, estatais e privadas, e agências internacionais de pesquisa e ajuda humanitária. A despeito da imensa maioria desses programas distribuírem anti-retrovirais para o tratamento da Aids, além de tratamento e profilaxia para a tuberculose (problema de saúde pública gravíssimo entre os mineiros sul-africanos), sobressaem problemas de sustentabilidade desse programas em médio prazo, dada a extensão da epidemia sul-africana que, em alguns contextos, chega a afetar $40 \%$ dos habitantes de algumas localidades. Mas, antes de tudo, tais programas se vêem às voltas com questões éticas complexas, uma vez que em contextos de prevalência muito elevada (ou seja, elevada proporção de pessoas infectadas em uma dada comunidade), a Aids (assim como a tuberculose) é, antes de tudo, uma questão familiar e comunitária. Sendo assim, como definir quais os potenciais beneficiários de tais programas: os trabalhadores? Os trabalhadores e suas famílias nucleares? Os trabalhadores e suas famílias estendidas? As comunidades de onde são recrutados os trabalhadores e onde vivem suas famílias?

Em se tratando de decisões que se traduzem em esperança de vida ou em uma sentença de morte para comunidades inteiras, questões éticas cruciais se apresentam. 
A estratégia adotada por Botswana de prover acesso universal aos anti-retrovirais e demais medicações anti-Aids, se mostra, neste sentido, mais coerente, e em tudo se assemelha à política brasileira de acesso universal. Cabe observar, entretanto, que se trata de um pequeno país, com 1,7 milhões de habitantes, enquanto a África do Sul conta com 44 milhões de habitantes, distribuídos em um território bastante mais amplo e com relevantes divisões regionais, sociais, étnicas e lingüísticas, ou seja, um verdadeiro desafio à implementação de políticas públicas de abrangência nacional, como a de acesso universal à medicação anti-Aids.

Cabe observar ainda que questões psicossociais complexas afetam sobremaneira a formulação e implementação de políticas de acesso universal à medicação anti-Aids, para além das dificuldades orçamentárias e logísticas. O exemplo paradigmático é aqui, ainda uma vez, a Rússia e as antigas repúblicas soviéticas, onde uma epidemia que afeta basicamente a população de usuários de drogas, num quadro institucional de escassa tradição democrática e de ausência de lideranças da sociedade civil que possam representar esta e outras populações marginalizadas, não conta com a coalizão virtuosa entre movimentos comunitários e Estado que poderia fomentar a adoção de uma política de acesso universal aos medicamentos anti-Aids. Tem sido extremamente difícil, mesmo em anos recentes, com a recuperação econômica da Rússia, carrear recursos para uma população malvista, estigmatizada e criminalizada. Mesmo os programas de substituição de heroína e outros opiáceos por metadona, adotados com êxito em inúmeros países em todo o mundo, continuam proibidos na Rússia e outras antigas repúblicas soviéticas, a despeito das repetidas tentativas por parte de 
organismos internacionais, como a própria Organização Mundial da Saúde (OMS).

A par das já mencionadas epidemias de grande magnitude na África subsahariana e Leste europeu, a segunda década da epidemia testemunha a emergência de diversas epidemias na Ásia, especialmente na sua região sudeste. Até então, as epidemias regionais asiáticas estavam basicamente restritas à tailandesa e alguns surtos epidêmicos isolados, em localidades que serviram de rota e entreposto de vendas do ópio e seus derivados.

Talvez o inegável sucesso obtido pela Tailândia no combate à epidemia em seu território, tenha transmitido a falsa impressão de que sucessos similares se repetiriam em outros países da região, em que a epidemia experimentaria, ao menos em suas fases iniciais, uma dinâmica similar à tailandesa, em que os usuários de drogas injetáveis e trabalhadores do sexo (especialmente do sexo feminino, embora exista a participação, menos expressiva, de trabalhadores do sexo transexuais e da assim denominada prostituição viril) desempenharam um papel central. Mas, provavelmente, em decorrência de problemas estruturais, como um maior contingente de pessoas pobres, dispersos em um território acidentado, e serviços de saúde menos organizados e acessíveis, o êxito das iniciativas tailandesas não se repetiu em países que emergiam de conflitos armados e/ou de transições políticas conturbadas, como Laos, Cambodja e Vietnã.

O sucesso da iniciativa tailandesa deve-se, basicamente, à adoção de uma política sistemática de utilização de preservativos no âmbito da vasta rede de estabelecimentos (prostíbulos, bares, casas de massagem etc.) onde se pratica o sexo comercial na Tailândia (o assim denominado, Programa 100\% Condom) e ao estabelecimento de uma política igualmente abrangente de tra- 
tamento de usuários de heroína e outros opiáceos (há que se ressaltar que as autoridades tailandesas têm sido muito pouco receptivas a iniciativas de redução de danos em moldes ocidentais).

A Tailândia se vê às voltas, hoje, com as dificuldades de oferecer tratamento a um vasto contingente de pessoas que adoeceram ao longo dessas mais de duas décadas de epidemia, ainda que sua epidemia não esteja mais se disseminando em ritmo explosivo, como no início da década de 1980. Apesar dos esforços recentes, o acesso universal à medicação anti-retroviral ainda não é uma realidade na Tailândia.

Nos países mais pobres e menos estruturados, como Laos, Cambodja e Vietnã, o desafio é, simultaneamente, reverter o curso acelerado da disseminação da epidemia e oferecer tratamento e apoio aos já infectados, com uma óbvia sobrecarga para serviços de saúde já saturados e para um contingente relativamente restrito de profissionais de saúde devidamente capacitados.

Mas o desafio maior está reservado a países de dimensões e população continentais, como a Índia e China, onde a epidemia, hoje, se assemelha a um complexo mosaico, com áreas e populações por ora não afetadas, e localidades e segmentos populacionais gravemente afetados, com quadros em tudo similares aos experimentados pela Tailândia nos anos 80, com incidência especialmente elevada entre usuários de drogas injetáveis e trabalhadores do sexo. Pode-se dizer, com razoável margem de certeza, que o destino da epidemia de Aids em todo o mundo dependerá, em grande medida, da dinâmica, em médio prazo, das epidemias chinesa e indiana. Caso as epidemias nestes dois imensos e superpovoados países escaparem dos atuais nichos, em termos de áreas e populações específicas afetadas, e se espraiar no sentido geográfico para o território daqueles países de 
um modo mais abrangente, afetando a assim denominada população geral, estaremos às voltas com uma pandemia de tal magnitude e extensão que ultrapassaria em muito a capacidade de resposta global, ainda que se tratando de países hoje considerados como potências emergentes.

Caso Índia e China consigam, de fato, manter suas epidemias sob controle, e mesmo reverter suas epidemias regionais, existe a chance de controlar a epidemia em nível global, desde que a África deixe de figurar como o 'continente esquecido' e constitua prioridade inequívoca das nações de todo o mundo, pois, não resta dúvida de que é impossível reverter a epidemia da África subsahariana a partir dos seus próprios recursos, sejam eles financeiros, técnicos ou referentes à mão-de-obra especializada.

Da perspectiva do Brasil, de uns poucos países em desenvolvimento em que o acesso à medicação anti-retroviral é universal (Botswana, Argentina, Chile, entre outros), ou ainda da perspectiva da maior parte dos países desenvolvidos, que contam com sistemas nacionais de saúde (como Reino Unido ou Canadá) ou que combinam (de forma nem sempre harmônica com relação às populações marginalizadas) seguros privados e legislações de proteção diversas, como os Estados Unidos da América, a situação é bem distinta da que descrevemos acima. Nestes países, a maioria das pessoas vivendo com Aids, devidamente identificadas como tais, recebe a medicação anti-retroviral potente ou Haart, que lhes garante uma vida plena e substancialmente mais longa.

A Haart determinou uma profunda inflexão na vida das pessoas infectadas pelo HIV/vivendo com Aids, uma revolução bem sucedida, ainda que não isenta de riscos e incômodos, que 
já dura uma década. No plano individual, a Haart determinou um aumento dramático da sobrevida dos pacientes com Aids e uma redução muito importante das doenças oportunistas, que afligiam o cotidiano desses pacientes e lhes impunham hospitalizações dolorosas e muitas vezes prolongadas. Ao livrar seu cotidiano dessas agruras, as pessoas vivendo com Aids puderam retomar suas vidas de forma plena.

Como disse, não há revolução sem riscos e incômodos, e o preço a pagar por esta tem sido de dupla natureza na esfera dos indivíduos vivendo com Aids. Trata-se de um tratamento complexo, que necessariamente combina três ou mais medicações, a serem tomadas (pelos critérios vigentes hoje) indefinidamente, de forma absolutamente regular e associadas a uma série de efeitos colaterais, alguns deles graves o suficiente, para fazer com que os pacientes tenham de interromper determinado esquema terapêutico e se vejam forçados a substituí-lo por outro.

Numa vertente complementar, mas específica, o tratamento nem sempre logra, em médio prazo, o efeito desejado, resultando em rebote (nova subida) da carga viral, que até então vinha se mantendo indetectável ou bastante baixa, sinalizando uma replicação (reprodução) viral bastante baixa, ao menos no compartimento (local do organismo) que é habitualmente avaliado - o sangue).

Em suma, seja devido a efeitos colaterais graves, seja devido à subida da carga viral, o que é denominado 'falha viral', que, habitualmente, se traduz em falha do ponto de vista clínico, o paciente se vê obrigado a tomar uma nova combinação de medicamentos. Numa perspectiva de tempo mais dilatada, trata-se de uma corrida, cabeça-a-cabeça, entre vírus e seres humanos, sem vencedor ou vencido à vista, em médio prazo. 
A cada ataque que lhes move a imunidade do organismo e os medicamentos, os vírus se reconfiguram, beneficiando-se dos deslizes do adversário como tomadas pouco regulares do medicamento ou mesmo o esquecimento de uma ou mais doses - o que é denominado 'problema de adesão' (aos medicamentos anti-retrovirais). Os vírus, essas máquinas spinozianas que vimos no capítulo 1, não se dão por achado sob o fogo cerrado da medicação e de um sistema imunológico que, aos poucos, se recompõe. Como nos velhos faroestes, escondem-se e preparam emboscadas quando se 'percebem' mais fracos, e partem para o combate aberto toda vez que uma recomposição bem-sucedida lhes permite retomar a luta cara-a-cara com medicamentos e elementos do sistema imunológico do indivíduo que estão atacando.

Ao menos por ora, não há meios de vencê-los em definitivo, apenas nocauteá-los com doses crescentes de agressividade, no que, da perspectiva do ser humano infectado, se traduz numa progressiva substituição de medicamentos menos potentes ou mais simples, ditos de primeira linha, por medicamentos progressivamente mais potentes e complexos, no que se convencionou denominar medicamentos de segunda linha.

Até o momento nenhuma das medidas tomadas se traduziu numa eliminação completa dos vírus ou erradicação, que, para os indivíduos infectados, se traduziria clinicamente em uma cura definitiva da Aids. Portanto, temos, enquanto membros conscientes e informados da humanidade (sejamos nós cientistas ou não) uma batalha permanente, sem data para terminar, a batalha de desenvolver remédios sucessivamente mais efetivos e potentes, para fazer frente a vírus que se redefinem e reconfiguram permanentemente. 
A outra alternativa seria a de 'cortar o mal pela raiz', seja através de uma nova geração de estratégias preventivas capazes de se somar às mudanças comportamentais espontâneas dos indivíduos, no sentido de adoção de um comportamento preventivo consistente frente ao HIV/Aids (por exemplo, utilizando preservativos em todas as relações sexuais), seja através de novas alternativas biomédicas no campo da prevenção, como a descoberta de uma vacina de fato eficaz ou o desenvolvimento de preparações microbicidas que impediriam que as mulheres se infectassem com o HIV ao terem relações sexuais desprotegidas com homens infectados. Até o momento em que redigo essas linhas, tais alternativas não estão disponíveis (como no caso das vacinas anti-Aids) ou quando estão (como no caso dos preservativos) não se dispõe de estratégias que consigam com que as pessoas as adotem de forma absolutamente consistente. Portanto, numa perspectiva mais dilatada no tempo, a Aids veio para ficar, e incomodar a geração dos nossos filhos e netos.

Mas a introdução em larga escala de uma medida profilática (por exemplo, uma vacina ou medicação que visa prevenir o desenvolvimento de uma doença, como na profilaxia da tuberculose) ou terapêutica (como no caso da própria Aids em adultos) com relação a uma doença infecciosa sempre se faz acompanhar de uma mudança bastante profunda nas condições ecológicas em que se dá a disseminação do agente infeccioso no âmbito das populações humanas.

Antes de incursionar por este último tópico, gostaria de fazer um parêntese para dizer que, em determinadas circunstâncias, não é possível distinguir com clareza o que é profilático (preventivo) e terapêutico (curativo) no âmbito do HIV/Aids. No campo da transmissão materno-infantil do HIV, a profilaxia se 
imbrica à terapia, fazendo com que mulheres grávidas tratadas precocemente com medicação anti-retroviral possam ter suas chances de gerar um bebê infectado pelo HIV reduzidas a praticamente zero, desde que inseridas num plano integrado de manejo da infecção e cuidados, que compreende ainda a realização de parto cesáreo, a não amamentação e o fornecimento de medicação aos recém-nascidos.

Neste caso (a mais bem-sucedida iniciativa de toda a história da luta contra o HIV/Aids) é possível eliminar definitivamente a Aids em uma das suas modalidades mais danosas "a Aids pediátrica (desde que existam os meios materiais, vontade política e capacidade técnica e gerencial).

Mas, retomando o raciocínio anterior, tal sucesso não pode ser sequer vislumbrado no campo da epidemia no seu conjunto, pelas razões que exponho a seguir.

O advento da Haart determinou uma recomposição de todo o campo do HIV/Aids no nível das populações com acesso efetivo a esse recurso indispensável. Ao fazer com que as pessoas vivam vidas mais longas e mais saudáveis, a Haart determina uma ampla recomposição das redes sociais onde essas pessoas estão inseridas. Ou seja, antes da Haart as pessoas vivendo com Aids viviam pouco e/ou estavam constantemente adoentadas, tendo imensa dificuldade de retomar suas vidas na sua plenitude. Com o advento da terapia, estas pessoas são capazes de retomar suas vidas plenamente, mas, como em tudo que é humano, demasiado humano, podem fazê-lo de forma consciente ou de forma arriscada, para sua própria saúde e dos demais. E nisso reside uma nova dimensão da prevenção, que irei detalhar a seguir - não mais a prevenção exclusivamente dirigida a evitar que as pessoas se infectem, como também a prevenção dirigida a pessoas que já 
estão vivendo com o HIV/Aids, no sentido de que elas não se reinfectem com o vírus (o que, ao contrário do que muitos pensam, se traduz em riscos substanciais), não se infectem com outros agentes infecciosos e não infectem seus parceiros. Os desafios são múltiplos e complexos, como veremos a seguir.

Inicio aqui por um tópico que certamente não é o mais relevante, em nível mundial, mas que me é bastante familiar: o tratamento e apoio psicossocial a pessoas que vivem com Aids, sob tratamento com a Haart, que consomem drogas e/ou álcool de forma importante.

Vivendo mais e melhor, abriram-se renovadas chances para que pessoas que consomem de forma abusiva e/ou são dependentes de álcool e drogas retomem suas vidas habituais, o que, em muitas circunstâncias, pode significar o retorno a padrões anteriores de consumo, incluindo os danos e riscos daí decorrentes. Embora tais pacientes não devam de forma alguma ser excluídos a priori dos benefícios da terapia, o manejo cotidiano constitui um desafio permanente às equipes de saúde, seja em função dos inegáveis efeitos colaterais cruzados de medicamentos, álcool e drogas; seja em função do comprometimento do status imunológico que elevadas doses de álcool e algumas drogas (como a cocaína) podem determinar; seja, de forma indireta e complexa, em função dos desdobramentos que um estilo de vida instável (extremamente comum entre dependentes graves de álcool e drogas) pode acarretar para o emprego sistemático e cuidadoso de esquemas terapêuticos complexos.

As dificuldades não param por aí. Alguns dos pacientes dependentes de drogas, especialmente injetáveis, estão freqüentemente infectados por outros vírus e bactérias, e essas co-infecções tornam bastante mais difícil o manejo clínico, tanto do HIV/Aids, 
como da eventual segunda ou terceira doença (por exemplo, hepatite $\mathrm{C}$ ou tuberculose). Além disso, sob efeito repetido de substâncias que alteram a percepção e a motricidade, o uso consistente de medidas preventivas, como os preservativos, constitui um desafio adicional.

A despeito de todas essas dificuldades, diversas iniciativas bem-sucedidas têm sido relatadas em todo o mundo, inclusive no Brasil. As estratégias que lograram obter êxito documentadas pela literatura internacional incluem: a atuação coordenada de equipes multidisciplinares, a co-localização de serviços diversos em uma mesma unidade de saúde (por exemplo, de um serviço de doenças infecciosas e de um serviço de tratamento de dependentes químicos ou um grupo de alcoólicos anônimos (AA)/narcóticos anônimos (NA)) e o manejo de cada paciente numa perspectiva absolutamente individualizada (o que é internacionalmente conhecido como 'manejo de caso' - case management).

Passo a seguir a um segundo tópico, igualmente complexo e desafiador - o aumento dos comportamentos de risco e o recrudescimento das infecções sexualmente transmissíveis (inclusive o HIV) entre gays, especialmente jovens, nos mais diferentes países desenvolvidos. A despeito de algumas indicações preliminares de que tal fenômeno estaria ocorrendo igualmente entre jovens heterossexuais, me atenho aqui aos recentes achados relativos aos gays, cuja questão é comprovadamente relevante.

A partir da metade da década de 1990, começou-se a observar em diversas comunidades gays, norte-americanas e européias, um retorno de práticas de risco, sendo mesmo algumas dessas práticas de risco (re)valorizadas como se constituíssem uma nova onda. Foi o caso do estímulo ao sexo desprotegido ou barebacking (literalmente 'cavalgar em pêlo'), difundido em festas gays e 
comunidades virtuais na Internet. Algo como uma temerária volta aos comportamentos de risco da era pré-Aids, em alguns contextos orientada pela idéia de uma espécie de roleta-russa e, paradoxalmente, em outros (e por vezes, nos mesmos, numa combinação estranha de representações psicossociais opostas) tributária de uma banalização da Aids, que, devidamente tratada, passa a ser vista como uma afecção trivial, para alguns, similar a um 'resfriado forte'.

Parecem ter contribuído para esse revival dos anos 80, o conflito intergeracional entre as lideranças comunitárias remanescentes dos anos 80 e os jovens gays, que iniciaram sua vida sexual na era pós-Haart, ou seja, em um momento em que as pessoas com Aids passam a viver vidas mais longas e saudáveis, e em que a epidemia perde, digamos assim, sua materialidade dramática (de pessoas extremamente emagrecidas e debilitadas). Contribuiria ainda, a própria recomposição das redes sociais, colocando em contato pessoas vivendo com Aids de gerações distintas, pessoas pertencentes a diferentes segmentos sociais, e com visões muitas vezes diversas e contrastantes, usuários de drogas e álcool, trabalhadores do sexo. Não que todos esses elementos não estejam presentes em toda a trajetória da epidemia, mas é que agora pessoas que estariam à margem de qualquer interação social, por adoecimento ou morte, retornam à cena, sentindo-se bem dispostas e otimistas com relação às suas perspectivas pessoais e em relação a uma suposta não-transmissibilidade do HIV a seus parceiros (suposta, ressalto, uma vez que níveis indetectáveis de vírus no sangue não necessariamente significam que alguém deixa de transmiti-los a terceiros).

Temos, portanto, na cena contemporânea, uma arriscada mistura de adolescentes e jovens adultos que se julgam invulne- 
ráveis ou que dizem que a Aids é coisa de 'bicha velha' (nas palavras de um entrevistado de um projeto de pesquisa desenvolvido no Brasil) e pessoas vivendo com Aids que julgam que, ao se tratarem (nem sempre de forma realmente sistemática, como julgam), podem dispensar quaisquer meios de proteção. Não por acaso, em diversas cenas gays, mundo afora, observase um recrudescimento de diferentes infecções sexualmente transmissíveis, inclusive da gonorréia retal (infecção caracteristicamente associada à prática do sexo anal desprotegido).

Uma nova geração de estratégias preventivas deve lidar com os desafios renovados da era pós-Haart, mostrando claramente que a Aids de fato se tornou crônica, mas não se tornou um 'resfriado forte', e continua presente na cena contemporânea, constituindo um problema de todos nós.

Fechando essa série de reflexões cabe mencionar os riscos de desenvolvimento da resistência viral, não apenas do ponto de vista individual (resistência secundária ao tratamento), como também da transmissão de cepas resistentes a novos indivíduos. Neste último caso, conhecido como resistência primária, um indivíduo pode se infectar com vírus resistentes a um amplo conjunto de medicamentos, dificultando e mesmo impossibilitando a adoção de quaisquer opções terapêuticas.

Há pouco foi noticiada em Nova York a emergência de um assim denominado 'super-vírus', resistente a qualquer medicação até então conhecida. Sensacionalismos à parte, trata-se de um risco real da era pós-Haart - a emergência e posterior disseminação de vírus multiresistentes.

Tenho trabalhado, com diversos colegas brasileiros, norte-americanos e canadenses, em pesquisas empíricas e na formulação de modelos conceituais e matemáticos de emergência e 
transmissão de vírus resistentes, no contexto de um retorno de comportamentos de risco e transmissão ampliada de outras infecções sexualmente transmissíveis. A conclusão a que chegamos, em consonância com diversos outros grupos de pesquisa, é de que a dinâmica da epidemia nos países em que a Haart está amplamente acessível dependerá do ajuste e entrechoque de forças opostas, incluindo os benefícios ao nível populacional da utilização da Haart (efetivamente reduzindo, mas não necessariamente eliminando, a capacidade das pessoas, sob tratamento, de transmitirem o HIV), os efeitos deletérios de um contingente de pessoas que não aderem ou aderem parcialmente à terapia e se vêem afetadas por vírus resistentes e, antes de tudo, da capacidade das pessoas vivendo com Aids de manterem ao longo do tempo comportamentos mais seguros.

Face à inevitável fadiga diante de medidas preventivas que se estendem hoje por quase três décadas e do inevitável otimismo vinculado a viver mais e melhor dos pacientes com Aids em tratamento com a Haart, trata-se de um desafio formidável.

De forma alguma, tais desafios devem se traduzir em desânimo ou descrédito dos inegáveis benefícios associados à Haart, mas, por outro lado, de forma alguma tais benefícios devem servir de munição à inércia, descaso e indiferença, seja por parte da sociedade, seja por conta de governos e profissionais de saúde.

Se as estratégias preventivas souberem se renovar e seguirem vigorosas e abrangentes e se o tratamento for cuidadosamente administrado e monitorado, podemos trilhar um caminho virtuoso, com uma epidemia de fato sob controle e com as pessoas vivendo com Aids, usufruindo plenamente dos benefícios da moderna terapia. Se o otimismo se traduzir em com- 
placência e indiferenças, podemos nos defrontar com uma epidemia com força renovada, com a disseminação de vírus resistentes.

Mais do que nunca, os ativistas e os profissionais de saúde estão frente a uma encruzilhada: a epidemia pode estar perto de um controle efetivo ou de um recrudescimento digno dos mais desastrados aprendizes de feiticeiro. O exemplo da tuberculose, freqüentemente resistente a diferentes medicamentos, deve nos servir de guia e inspiração, para que não nos vejamos surpreendidos com a volta de algo que os países ocidentais julgavam coisa de um passado distante, e que vem assustando o mundo desenvolvido e em desenvolvimento, dos bairros empobrecidos de Nova York ao sistema penitenciário da Rússia e do Leste europeu. 


\section{I Espelho, Espelho Meu}

Neste início de século XXI, a epidemia de Aids segue em expansão, com marcadas assimetrias regionais e populacionais. Os padrões de disseminação da epidemia conformariam hoje uma espécie de espelho invertido das riquezas do mundo.

Em um grupo, estão os países desenvolvidos, em que a epidemia se estabilizou ou foi revertida. Tal dinâmica pode ser observada nos países que não são apenas ricos, mas que contam com sociedades homogêneas, cujas desigualdades sociais são pouco relevantes. Nestes países, a epidemia arrefeceu e, a não ser que ocorra algo totalmente inesperado, deverá ter sua velocidade de disseminação paulatinamente reduzida, até que a Aids se torne um problema eventual, quase um 'evento-sentinela', termo com o qual a vigilância sanitária designa eventos raros, que pela sua própria ocorrência denotam alguma falha ou anomalia das medidas de saúde pública em curso.

Apenas para permitir ao leitor compreender do que se está falando aqui, utilizarei um exemplo tradicional de evento-sentinela: a morte de um paciente em decorrência de apendicite. Neste caso, nos países que contam com uma vigilância sanitária de bom padrão, esta morte deve ser minuciosamente investigada, pois se trata de uma patologia de diagnóstico simples, seguido de intervenção cirúrgica padrão, que não deveria, em nenhuma circunstância, resultar em óbito. Da mesma forma, é possível que a notificação de um caso de infecção pelo HIV (pois estes países 
contam com um sistema de notificação de infecções e não apenas com um sistema de registro de casos de Aids) venha, em um futuro próximo, a constituir um evento-sentinela em países como a Finlândia, Noruega, Suécia e Dinamarca.

No que poderíamos denominar de segundo grupo de países, estão as sociedades ricas, mas heterogêneas, seja em função da marcante desigualdade econômica, seja em função da exclusão de natureza social e/ou étnica de contingentes expressivos da população. O exemplo paradigmático aqui é o dos Estados Unidos da América. Ao longo de duas décadas e meia, uma epidemia que atingiu, no início dos anos 80 , predominantemente, a comunidade gay, branca, de classe média, se transmutou em uma epidemia que afeta, hoje, de forma absolutamente desproporcional os negros e os imigrantes, especialmente latinos. Os negros, ou afro-americanos, que correspondem, grosso modo, a $13 \%$ da população norte-americana perfazem hoje 50\% dos novos casos de Aids notificados naquele país. Da mesma forma, os imigrantes (em relação aos quais as estatísticas estão bastante subestimadas, em virtude do caráter ilegal e oculto em que vivem muitos deles) vêm sendo desproporcionalmente afetados pela epidemia, especialmente alguns segmentos latinos, como os porto-riquenhos. Existe aí um claro contraste com a espiral ascendente de prevenção efetiva, pleno acesso a meios de prevenção e tratamento, através de recursos próprios e diferentes modalidades de seguros sociais privados. Estes recursos materiais e simbólicos fizeram com que a maioria branca, de classe média, com maior nível educacional e ocupações mais bem remuneradas adotasse de forma consistente, ao longo da trajetória individual de cada um e do seu grupo social de referência, medidas preventivas. Caso se infecte ou adoeça, este segmento 
populacional conta com as melhores alternativas de tratamento e monitoramento.

Como vimos no quarto capítulo, a reversão dessa espiral ascendente pode ocorrer, em médio e longo prazo, a partir dos fenômenos discutidos anteriormente, referentes ao otimismo vinculado à Haart e à recomposição das redes sociais. Mas esta é, por ora, uma tendência preocupante, mas não uma dinâmica majoritária. Ainda que segmentos específicos da população branca, de classe média, possam estar sendo crescentemente afetados, como os jovens gays, ainda é cedo para avaliar as conseqüências desta dinâmica específica sobre os estratos médios como um todo, e, até o momento, a tendência mais abrangente neste segmento populacional majoritário é de estabilização da epidemia.

Entre os desfavorecidos, em contrapartida, existiria uma espiral descendente ou uma 'sinergia de males' (ou 'sindemia', na expressão cunhada por Merril Singer) em locais onde se congregam populações marginalizadas, que habitam guetos sociais, raciais ou lingüísticos, com elevadas proporções de pessoas desempregadas, à margem de qualquer proteção social e que procuram se manter ocultas mesmo frente a programas comunitários de auxílio a pessoas sob risco e/ou vivendo com HIV e Aids (por serem imigrantes ilegais, por estarem sob condicional e não desejarem explicitar que, ao consumirem drogas, estão violando as regras da condicional, por estarem 'juradas' de morte por gangues rivais etc.) não encontram meios de se proteger de forma consistente, às voltas que estão com outras necessidades prementes, como ter o que comer, arranjar um local para dormir, ou mesmo arranjar meios de adquirir a próxima pedra de crack que irão fumar. 
Nestes locais (que lembram as nossas favelas), assolados pela violência estrutural, pelo tráfico de drogas, por elevadas taxas de infecções sexualmente transmissíveis, tratáveis (como a sífilis) ou ao menos evitáveis (como a infecção pelo Papiloma Vírus Humano, agente causador do câncer de útero), e ainda, por taxas elevadas de infecção pelo HIV (o que, tecnicamente, é denominado background prevalences), cada potencial interação de risco (como fazer sexo desprotegido ou injetar drogas com a seringa usada por outro usuário de drogas) tem uma enorme chance de se transformar em risco efetivo de infecção pelo HIV. Tudo contribui para este risco ampliado, uma vez que as demais infecções sexualmente transmissíveis aumentam, em muito, as chances de transmissão do HIV, e cada evento de compartilhamento de equipamentos de injeção tem uma enorme chance de colocar em contato uma pessoa infectada pelo HIV e/ou pelos vírus das hepatites $\mathrm{B}$ e $\mathrm{C}$ e algum novato, que inicia ali o consumo de drogas injetáveis, e encontrou no companheiro mais velho e experiente o 'guia' que vai lhe ensinar como injetar drogas, o mais das vezes 'graduando' a dose (visando evitar uma overdose) na própria seringa que acabou de utilizar.

Nestas comunidades empobrecidas, não é de surpreender que medidas tópicas sejam de pouca ou nenhuma efetividade, pois se trata aqui da necessidade de transformar toda uma estrutura que perpetua não só a disseminação do HIV, mas toda sorte de doenças e agravos médicos e sociais. Uma das principais limitações postas à prevenção nestes locais é a descontinuidade das ações, ameaçadas por confrontos violentos entre gangues rivais ou entre traficantes e a polícia. Para quem já atuou em prevenção em comunidades empobrecidas no Brasil, tais relatos norte-americanos soam demasiado familiares. 
Da mesma forma, sociedades não tão ricas como a norteamericana, mas segregadas, como a França contemporânea, cujas profundas fissuras vêm sendo expostas nos noticiários de todo o mundo, encerram, em seu bojo, epidemias em declínio, por exemplo, no coração de Paris, e comunidades afetadas pelas já mencionadas sindemias, como nos banlieues, onde se congregam imigrantes, especialmente do Norte da África, com pouco acesso à educação formal, desempregados e às voltas com problemas similares aos norte-americanos de violência estrutural e tráfico de drogas. Nestes locais, a epidemia de HIV e Aids, além, é claro, de um sem número de problemas sociais e de saúde pública, está longe de qualquer perspectiva de controle.

Diversos pesquisadores brasileiros, inclusive o nosso grupo de pesquisa, na Fundação Oswaldo Cruz (Fiocruz), têm evidenciado dinâmicas similares da epidemia em território brasileiro, país bastante mais pobre do que os Estados Unidos ou a França, e marcado por uma desigualdade social bastante mais pronunciada. Assim como naqueles países, as inúmeras e profundas fissuras da sociedade brasileira têm dado lugar a epidemias de cunho local ou mesmo regional, ainda que, no conjunto, a epidemia brasileira esteja, grosso modo, estabilizada.

Retomando o raciocínio do primeiro capítulo, cabe frisar que o HIV, como qualquer outro agente infeccioso, não tem qualquer opção preferencial por pobres, assim como jamais teve qualquer simpatia ou antipatia por gays ou hemofílicos. O vírus, simplesmente, e num sentido metafórico, se beneficia das linhas de fragilidade das redes sociais onde é introduzido. Se estas vulnerabilidades são decorrentes de comportamentos de risco de pares de parceiros sexuais ou de todo um grupo que compartilha uma injeção de cocaína numa cela de um presídio, isto, da 
perspectiva (virtual) dos vírus, lhes é inteiramente indiferente. Guiado pela missão primeira e fundamental de persistir, custe o que custar, sua disseminação seguirá as cadeias de transmissão que se lhes apresentarem mais favoráveis, indiferentes a quaisquer psicologias ou sociologias que lhes queiram atribuir.

De volta aos países e sociedades mais afetadas pela epidemia em todo o mundo, cabe ressaltar que a epidemia pode persistir indefinidamente na África subsahariana, em níveis inaceitavelmente elevados, mas não mais de forma explosiva. Neste processo, tecnicamente denominado de endemização, a Aids poderia se tornar a malária do século XXI, dizimando, silenciosamente, milhares de vida a cada ano, sem que isso mereça qualquer notícia na imprensa leiga ou desperte a comoção das pessoas, que se espantam e surpreendem com eventos de aparecimento súbito, como um ataque terrorista, mas se mostram indiferentes diante do lento holocausto provocado pelas guerras civis na África, ou pela disseminação progressiva da malária ou da tuberculose naquele continente. De forma premonitória, o poeta anglo-americano T. S. Eliot disse certa vez que "o mundo não acabaria em uma explosão, mas com um suspiro”.

A perspectiva atual com relação à Aids, seja do ponto de vista coletivo ou individual, é de controle, se assim o permitirem as circunstâncias, mas não de erradicação em nível coletivo ou cura no nível individual. Esta afirmativa talvez pareça desalentadora para o leigo, mas não difere em nada do destino da imensa maioria de doenças que assolam o mundo.

A despeito do formidável progresso científico e tecnológico, pouquíssimas doenças infecciosas, como a varíola, foram de fato erradicadas. Mesmo doenças praticamente erradicadas, como a poliomielite (paralisia infantil), reemergem de quando 
em quando. Os últimos episódios de sua reaparição são paradigmáticos dos obstáculos com que se depara a saúde pública quando tenta traduzir em ações concretas suas formulações. Casos de poliomielite têm sido detectados em alguns países africanos, especialmente naqueles em que conflitos armados permanentes acabaram por desmontar os já frágeis sistemas de saúde locais. Foram notificados também, recentemente, casos de poliomelite em uma comunidade religiosa norte-americana que não aceita a vacinação (assim como outras conquistas da ciência contemporânea). Ou seja, em função de constrangimentos estruturais ou da decisão de pessoas ou grupos em não adotar determinada medida preconizada pelas autoridades de saúde, os resultados práticos de um conjunto de medidas ficam aquém do esperado a partir das formulações teóricas ou dos resultados de simulações desenvolvidas em computador.

Se tais barreiras se antepõem à erradicação de doenças para as quais se dispõem de vacinas cuja efetividade e segurança se aproxima de 100\%, o que dizer do campo do HIV/Aids em que, a despeito de inúmeros esforços, não foi possível obter, até o momento, vacinas minimamente eficazes? As pesquisas mais recentes em HIV/Aids já não consideram mais a hipótese de uma futura vacina 100\% eficaz e efetiva, mas sim a possível utilização de vacinas que induziriam proteção apenas parcial, não evitando, por exemplo, a infecção pelo HIV, mas evitando que a infecção pelo HIV progredisse para a síndrome clínica (Aids).

Os riscos da aplicação dessas vacinas de proteção parcial são conhecidos e comparáveis aos riscos associados à utilização em massa de anti-retrovirais, discutidos anteriormente. Além da possibilidade de natureza biológica de involuntariamente selecionar um supervírus (ao eliminar seus competidores mais fracos, 
incapazes de suplantar a proteção conferida pela eventual vacina parcialmente protetora), existe a hipótese mais complexa e desafiadora de que uma suposta proteção conferida pela aplicação em massa da vacina dê lugar a uma percepção equivocada de invulnerabilidade por parte dos vacinados e seus pares e a um descuido perigoso com relação à prevenção. Portanto, seja lá qual for a iniciativa de cunho biomédico a ser adotada num futuro próximo, cabe sempre esclarecer que ela jamais será uma 'bala mágica' (expressão familiar em língua inglesa - magic bullet), capaz de derrotar o inimigo com um único tiro. Não existe qualquer perspectiva de médio e mesmo longo prazo que não compreenda a implementação conjunta e integrada de inovações no campo da biomedicina e estratégias de cunho psicossocial, compreendendo o esclarecimento, aconselhamento e mesmo a assistência psicoterápica, caso necessário (por exemplo, de um indivíduo vacinado que se testa, recebe um resultado positivo, em decorrência da imunidade induzida pela vacina e não da infecção, e reage com um quadro de depressão e ideações suicidas).

Portanto, no plano coletivo, a proposta viável por ora, é coordenar todos os esforços possíveis no sentido de manter a epidemia sob controle, tendo claro que em regiões mais afetadas, quase invariavelmente mais pobres, tal esforço não será possível a partir apenas de ações locais, mas tão-somente a partir de um esforço global, que complemente as inúmeras deficiências materiais e de pessoal capacitado dos países mais afetados pela epidemia e que se deparam com inúmeros outros problemas, como a malária, a tuberculose, a fome ou as guerras civis. Um exemplo claro disso é o colapso do sistema educacional de diversas comunidades africanas, a partir do adoecimento e morte de toda uma geração de professores. 


\section{A PERSPECTIVA dAS PESSOAS VIVENDO COM HIV / AIDS}

No plano dos indivíduos sob tratamento, as perspectivas são em tudo semelhantes às que mencionamos na esfera coletiva. Não existe, em médio prazo, nenhuma perspectiva de erradicação da infecção pelo HIV e conseqüente cura da Aids. Ainda uma vez cabe observar que a imensa maioria das doenças que nos afetam não são curáveis, mas sim manejáveis, a partir de um processo de sua transformação em uma doença crônica. Este é o caso, por exemplo, do diabetes melito ou da hipertensão arterial, que, em momentos anteriores da humanidade matavam em prazo muito curto, e que, hoje, devidamente controladas, não ameaçam de imediato a vida dos pacientes por elas afetadas, evoluindo de forma crônica, sempre a demandar cuidados médicos e monitoramento.

Da mesma forma, é possível hoje controlar a infecção pelo HIV/Aids e devolver aos pacientes com Aids uma vida substancialmente prolongada e plena, não existindo, entretanto, perspectivas de interrupção do tratamento ou a possibilidade de erradicar os vírus de todo e qualquer local do corpo onde eles encontrem refúgio. Habitualmente, é possível erradicá-los ou quase erradicá-los de lugares centrais à sua disseminação, como a corrente sangüínea, o que se traduz em sucessivos exames com carga viral (expressão numérica do contingente de vírus presentes em determinado local) indetectável, o que é, quase sempre, compreendido como 'carga zero'. A questão é, infelizmente, mais sutil, pois em qualquer iniciativa de mensuração não está em jogo tão-somente o objeto a ser medido, como também o instrumento de medida. Portanto, o que sabemos hoje com certeza é 
que é possível manter, por tempo prolongado, uma carga viral indetectável na corrente sangüínea de um indivíduo sob tratamento adequado, embora não saibamos, ao certo, se esta carga se mantém, de fato, zero, ou na verdade indetectável em função dos limites de detecção dos nossos instrumentos de medida. Sabe-se, hoje, com certeza, que o vírus é capaz de ficar aparentemente adormecido por longo período nos assim denominados 'santuários', locais onde - como os antigos foragidos que buscavam abrigo em templos religiosos - , eles se escondem e se 'fingem de mortos', à espera de uma chance de reemergirem.

Portanto, da perspectiva da clínica dos pacientes vivendo com Aids, cabe administrar da melhor forma possível a emergência de problemas ao longo do período de tratamento, período hoje sinônimo de toda a vida de cada indivíduo. A responsabilidade dos profissionais de saúde que lidam cotidianamente com cada um dos pacientes é enorme, e não deve nunca se limitar a prescrever remédios e solicitar e analisar exames. Profissionais e pacientes são parceiros e partícipes dos projetos de vida de cada indivíduo vivendo com Aids, assim como já ocorre com os profissionais que cuidam de pacientes diabéticos. Diversas estratégias vêm funcionando de forma muito satisfatória em todo o leque de doenças crônicas, incluindo associações de defesa de seus interesses e de apoio de/a pacientes vivendo com diversos agravos à saúde, grupos de mútua-ajuda, além da indispensável oferta de cuidados individualizados, necessariamente prestados por equipes multidisciplinares.

Novos desafios vêm se apresentando no campo do manejo das pessoas vivendo com HIV/Aids, alguns deles decorrentes do sucesso mesmo da terapia anti-retroviral, pois, uma vez que as pessoas vivam mais (estejam elas infectadas ou não pelo HIV), 
aumentam as suas chances de se depararem com doenças que se apresentam no transcurso dos anos. Um desses desafios, além da já mencionada emergência da resistência viral, é o aparecimento de novos efeitos colaterais dos medicamentos, como a lipodistrofia e a síndrome metabólica correlata, com aumento da glicemia (níveis de glicose) sangüínea e das taxas de lipídeos e suas frações (como colesterol e triglicerídeos) no sangue. Talvez para a surpresa dos leitores, acostumados à imagem de um paciente extremamente debilitado e emagrecido, diversos pacientes hoje, não só ganham peso rapidamente, como se vêem às voltas com o sobrepeso e distúrbios do metabolismo dos açúcares e lipídeos, com as conseqüências que todos já conhecem, de aumento da freqüência de doenças coronarianas, diabetes e hipertensão arterial. Diferentemente, porém de outros pacientes com distúrbios metabólicos, os pacientes com Aids em uso de determinadas medicações apresentam, comumente, uma redistribuição de tecido gorduroso bastante peculiar e esteticamente desagradável para os que a experimentam (com depósito de gordura sob a forma de 'giba de búfalo', na região superior do tronco, em paralelo à perda de massa gordurosa em outras regiões, como a face).

Há algum tempo atrás fui procurado por colegas que desejavam avaliar um programa de condicionamento físico para pacientes vivendo com Aids em uso da Haart. Infelizmente, o trabalho não avançou, o que não quer dizer que esta não seja uma questão prioritária nessa nova época de pessoas vivendo com Aids com sobrepeso e mesmo obesidade, e não mais emagrecido.

Outras questões também emergiram à medida que os pacientes passaram a viver mais, e uma das mais relevantes, especialmente na população com a qual trabalho cotidianamente, os 
usuários de drogas injetáveis, é o manejo de pacientes coinfectados pelo HIV e por outros vírus, sendo especialmente desafiador o manejo da coinfecção pelo HIV e pelo vírus da hepatite $\mathrm{C}$ (VHC ou HCV). Em se tratando de dois vírus de expressão lenta, mas bastante agressivos nos seus efeitos em médio e longo prazos, a coinfecção HIV/HCV deve ser manejada por equipes multiprofissionais com experiência em ambas as infecções e suas respectivas terapias medicamentosas.

Não me aventuraria aqui por outros caminhos, que me são pouco familiares, mas cabe ao menos mencionar outros problemas da clínica contemporânea do HIV/Aids, como a coinfecção HIV e tuberculose multiresistente, que vem emergindo em diversos contextos, em todo o mundo, ou o aparecimento, habitualmente ao longo de um tempo dilatado, de problemas neurológicos em pacientes infectados pelo HIV, ou ainda o complexo manejo de diferentes tumores em pacientes vivendo com Aids.

Aqui, como em todos os demais campos da medicina, viver mais significa não necessariamente viver melhor, embora viver melhor seja uma realidade fartamente documentada na clínica contemporânea em HIV/Aids, mas, infelizmente, por vezes, estar mais sujeito às doenças mais prevalentes entre os mais velhos (como os cânceres e diversos problemas neurológicos). Também aqui, o sucesso logrado em cada etapa se traduz também em novos desafios, numa luta sem tréguas da ciência e da medicina por uma vida mais longa, mais saudável e mais digna.

\section{DE VOLTA AO COLETIVO}

Retornando à dimensão propriamente coletiva da questão, lanço mão novamente da idéia do pesquisador norte-americano Morse (vide capítulo inicial) de que não é possível, em um mun- 
do globalizado e interconectado, impor barreiras à disseminação das epidemias, mas sim definir regras do tráfego viral. Tal proposta não é de modo algum simples, pois quaisquer iniciativas neste sentido descambam, muito facilmente, para propostas xenófobas, que se mostraram tão estúpidas e variadas como inúteis (quando não, fracamente contraproducentes) no caso da Aids. Certamente são de triste memória para os mais velhos, como eu, propostas, que em tudo lembravam as propostas nazistas, de, por exemplo, tatuar símbolos nas nádegas de homossexuais masculinos vivendo com Aids, formulada por um legislador norte-americano que os anos fizeram se tornar anônimo, no início da década de 1980.

Combinar medidas de fato efetivas com o respeito aos direitos humanos fundamentais, como o de ir e vir, liberdade de expressão e associação, liberdade de culto etc. constituirá um desafio posto a todas as sociedades e governos de todo o mundo com relação à pandemia que se avizinha, a da gripe das aves. Por ora, trata-se de sacrificar aves e colocar populações de pequenos vilarejos sob observação (e eventual quarentena). Mas o que irá acontecer caso (algo extremamente provável) o vírus passe a ser transmitido de pessoa para pessoa, sem a necessária mediação das aves, e se torne um fenômeno urbano?

Como havia dito anteriormente, o pânico provocado pelas epidemias costuma despertar o que há de melhor e de pior em cada um de nós, num leque que vai da solidariedade ao mais abjeto preconceito e xenofobia. Está em nossas mãos reagirmos a esse novo desafio posto pela gripe das aves de forma mais sensata e democrática possível, sabendo que esta próxima pandemia está longe de ser a última, e que as constantes mudanças climáticas e a devastação sistemática dos diferentes 
ecossistemas devem acelerar a eclosão e a disseminação de novas pandemias.

Os apelos à preservação dos nossos irmãos, símios nãohumanos, têm surtido pouco efeito, e é infelizmente bastante provável que, exterminados ou preservados em algumas poucas reservas e zoológicos, eles deixem de ser o hospedeiro favorito de uma série de agentes infecciosos, que com eles convivem há milhares de anos, de forma relativamente harmoniosa. Ausentes os símios não-humanos, os vírus encontrarão os caminhos - hoje ainda pouco conhecidos - que os levarão a nós, símios humanos.

De forma similar, parece hoje impossível fazer com que a China, a potência emergente dos nossos dias, reformule com a profundidade necessária as suas criações de aves e suínos, de onde emergem, invariavelmente, todas as pandemias de gripe (influenza) que assolam o mundo há pelo menos um século. Como fazer com que um bilhão e trezentos milhões de pessoas sejam alimentadas, se forem destruídas suas fontes básicas de proteína animal (as centenas de milhões de pequenas granjas de aves e suínos), que se estruturam há milênios junto a córregos e pequenos lagos, onde habitam diferentes aves aquáticas (reservatório último dos vírus da influenza). Seria ingênuo acreditar que tais vias de tráfego viral possam ser definitivamente interrompidas ou desaparecer no horizonte dos nossos dias ou mesmo de nossos netos. É mais realista saber que conviveremos por décadas, talvez séculos, com novas ondas de influenza vindas da China, e que cabe a nós monitorá-las cuidadosamente, como está sendo feito com a gripe das aves, prevenindo novos surtos sempre que possível, lançando mão de todos os meios de que dispuser a ciência do futuro, respeitadas as prerrogativas democráticas. 
Ao leitor, toda essa sucessão de pragas e pestes deve soar nada menos do que apocalíptica, mas o tom aqui não é de alarde sensacionalista (do qual já estamos todos fartos), mas do cuidado que devemos devotar a este frágil e complexo planeta, que nem conhecemos direito, mas que estamos sempre prontos a espoliar e maltratar.

As dificuldades que ora enfrentamos, e que as novas gerações enfrentarão de modo crescente e agudo, devem nos servir de alerta, mas não amesquinhar nossa capacidade de criar e agir de forma conseqüente.

Os indivíduos, famílias e comunidades que lutaram contra a então nascente epidemia da Aids em um momento em que não havia quaisquer alternativas reais de tratamento, ou os nossos concidadãos do século XXI que vivem em comunidades na África, e que, a despeito dos imensos avanços da ciência, não têm qualquer acesso aos medicamentos que salvariam suas vidas, têm uma imensa e tocante lição a nos ensinar. Que sejamos minimamente justos, solidários e comprometidos com o destino da nossa frágil humanidade, às voltas com sucessivas crises, de origem a mais diversa.

Quero terminar este pequeno livro, que procura recuperar a memória de uma epidemia recente e das pessoas por ela afetadas, com as palavras de um grande brasileiro, que viveu uma longa e produtiva vida, para surpresa dele mesmo, que se julgava condenado a uma morte precoce. Falo de Manuel Bandeira, o mestre da poesia do nosso Modernismo, que contraiu a tuberculose, então fatal, ainda muito jovem, o que o fez mudar totalmente de planos, internar-se em um asilo para tuberculosos na Suíça e tornar-se poeta, no fio da navalha da vida e da morte, como descreve no magnífico 'Itinerário de Pasárgada', de cunho biográfico. 
Sempre humilde, enfrentando o destino ingrato de cabeça erguida, Bandeira, para nossa felicidade, viveu uma vida longa e incrivelmente fecunda, tendo incursionado com êxito pela poesia, ensaio, tradução, autobiografia, crônica, além dos textos didáticos que subsidiaram seu sereno magistério. Apaixonado pela vida e acossado pela morte, pôde enxergar, como poucos, a plenitude de cada momento, como no trecho do poema que se segue, os versos finais de 'Embalo':

Azuis de águas e céus

Sou nada, e entanto agora,

Eis-me centro finito

Do círculo infinito

De mar e céus afora.

- Estou onde está Deus. 


\section{SUgESTÕES DE LEITURAS}

Uma das dificuldades persistentes na compreensão de fenômenos de base biológica nova e complexa é a necessidade de conhecer os fundamentos da biologia moderna. Freqüentemente, os críticos do assim denominado 'modelo biomédico' confundem numa única expressão, aparentemente singela, questões referentes à biologia e à medicina (que, ao contrário da biologia, não é uma ciência, mas sim um entroncamento de saberes de ciências diversas, incluindo as ciências classificadas como biológicas, sociais e humanas; práticas; relações com o mercado e o Estado etc.), além de utilizarem, de forma inapropriada, o próprio conceito de 'modelo' (antes instância mediadora, do que fôrma, na epistemologia moderna). Minha opinião pessoal é que por desconhecerem o avanço do conhecimento biológico ao longo de todo o século XX, gastam seu tempo atacando chavões inteiramente superados no âmbito da biologia, ou, como se diz na gíria, 'chutando um cachorro morto'.

Portanto, um bom começo é compreender a biologia para além das habituais ortodoxias e reducionismos. Minha sugestão inicial é percorrer a obra daquele que é considerado o Darwin do século XX, Ernst Mayr, começando talvez pela sua última e mais concisa obra Biologia, Ciência Única (The Uniqueness of Biology), publicada em português pela Companhia das Letras (Rio de Janeiro) em 2005, pois, como afirmou seu irônico autor, que acabou de redigi-la aos 100 anos, não haveria tempo para redi- 
gir obra posterior e não havia dúvida de que esta, sim, se beneficiaria da experiência acumulada.

Seu parceiro de aventuras ornitológicas, Jared Diamond, integra de forma instigante a história das civilizações a uma visão moderna da biologia evolucionista e ecologia, em livros como Armas, Germes e Aço (2001), que debate, explicitamente, a história das doenças infecciosas no quadro da história humana, e Colapso: como as sociedades escolhem o sucesso ou o fracasso (2005), ambos da Editora Record (Rio de Janeiro).

Fechando as sugestões no âmbito da biologia, menciono ainda o volume $A$ Recepção do Darwinismo no Brasil, organizado por Heloisa Maria Bertol Domingues, Magali Romero de Sá e Thomas Glick (Rio de Janeir: Editora Fiocruz, 2003), que aborda as sucessivas releituras e desenvolvimentos da biologia evolutiva em nosso país.

$\mathrm{Na}$ interface entre a biologia e dois dos ramos da biomedicina contemporânea, imunologia e virologia, situam-se o norteamericano Paul Ewald, Evolution of Infectious Diseases (Nova York: Oxford University Press, 1994) e o holandês Jaap Goudsmit, $V$ iral Fitness: the next $S A R S$ and west nile in the making (Nova York: Oxford University Press, 2004), autores de obras que, até onde é do nosso conhecimento, permanecem inéditas em português. O livro do primeiro está hoje defasado com relação à questão específica da Aids, mas é bastante atual do ponto de vista conceitual. O livro de Goudsmit, considerado por muitos o mais influente pesquisador europeu em HIV/Aids, é bastante atual e traz idéias e achados inovadores sobre as complexas inter-relações entre vírus e seus parasitados (humanos e nãohumanos), no contexto de um meio-ambiente próximo do colapso, como discutido por Diamond. 
Os textos seminais da pesquisa biomédica em HIV/Aids, nos seus momentos iniciais, foram reunidos na coletânea Aids: papers from science 1982-1985 (Washington, D.C.: American Association for the Advancement of Science, 1986) que encontrei, por acaso, em uma calçada da Rua São José, centro do Rio, em um dia chuvoso, e que adquiri por uma bagatela de um ambulante encharcado. Analisei, em parceria com meu ex-orientador, Euclides Castilho, alguns dos achados compendiados nesta coletânea no artigo: "Aids (1981-1997): o rastro da tormenta", Revista USP, 33: 6-19, 1997. O tratamento da infecção pelo HIV e da síndrome clínica (Aids) nunca mais foram os mesmos desde os trabalhos de David Ho e seus inúmeros colaboradores. Não se trata de leitura fácil para o não especialista, mas constituem inegável marco de avanço científico. Se tivesse que destacar os meus preferidos dentre suas centenas de artigos ficaria com aqueles redigidos em parceria com o mago austríaco da biomatemática, Martin Nowak, mas esta é apenas uma preferência pessoal. As referências dos trabalhos desses autores, assim como de Don des Jarlais, podem ser encontradas na base bibliográfica PubMed (www.ncbi.nlm.nih.gov/entrez/), acesível ao público em geral.

A epidemiologia tradicional cometeu equívocos grosseiros com relação à dinâmica da epidemia de Aids nos seus primórdios. Uma das razões subjacentes a esses equívocos é o fato de os reducionismos de qualquer sorte constituírem, invariavelmente, opções tentadoras, seja por sua simplicidade enganosa, seja por conferirem uma aura de cientificidade aos preconceitos rasteiros. A segunda razão que me parece alimentar equívocos e preconceitos é a perigosa mistura de ignorância e soberba. Tivessem os epidemiologistas de então lido os trabalhos pioneiros de Alden Klovdahl (sociólogo que atua em Camberra, Austrália), e 
o pior talvez tivesse sido evitado. Enfim, ainda é tempo de conhecer um pouco dos estudos inovadores de redes sociais em HIV/Aids, através da obra de uma das suas mais agudas proponentes, Martina Morris, em seu livro Social Networks Epidemiology, ainda inédito em português (Nova York: Oxford University Press, 2004).

No campo das ciências sociais e humanas, avultam coletâneas de estudos históricos como Aids: the burdens of history (Berkeley: University of California Press, 1988) e Aids: the making of a chronic disease (Berkeley: University of California Press, 1992). Ou ainda as instigantes reflexões de Jonathan Mann, trágica e precocemente desaparecido, em obras como Aids in the World (Cambridge: Harvard University Press, 1992), publicado no Brasil como Aids no Mundo (Rio de Janeiro: Relume Dumará-AbiaIMS/Uerj, 1994). Também deste último autor, vale conferir Health and Human Rights: a reader (Londres: Routledge, 1999), que apresenta a inovadora proposição de pensar a Aids e a saúde pública em geral nos marcos dos direitos humanos.

A vasta, criativa e polêmica obra de Paul Farmer combina sua vivência prática em medicina, desenvolvida em contextos os mais adversos, especialmente no Haiti, aos seus amplos conhecimentos de antropologia e seu ativismo social. Nas suas obras mais recentes, Infections and Inequalities: the modern plagues (Berkeley: University of California Press, 1999) e Pathologies of Power: health, human rights and the new war on the poor (Berkeley: University of California Press, 2003), até onde é do meu conhecimento, inéditas em português, Farmer amplia sua perspectiva, seja no seu campo de atuação (tematiza especificamente a tuberculose, além da Aids), escopo geográfico (que, além do Haiti, diz agora respeito aos mais diversos contextos onde vivem os 'deserdados 
da terra', da América Central ao Leste europeu), ou ainda nos conhecimentos que informam sua reflexão (que incorporam a Teologia da Libertação, inclusive brasileira, e a literatura de ficção e a poesia). Poucos autores contemporâneos guardam uma sintonia tão profunda com o "humano, demasiado humano".

Finalizando, registro que os textos de Borges e Manuel Bandeira, que abrem e concluem este pequeno volume, foram extraídos de suas Obras Completas, editadas, respectivamente, pela Emecé (sob este mesmo título) e Nova Aguilar (Poesia e Prosa, em dois volumes). Quanto a T. S. Eliot, vale consultar Complete Poems and Plays: 1909-1950 (Orlando: Harcourt Brace \& Company, 1980), em que pode ser encontrado o poema "The hollow men", de 1925. 
